Journal of Educational

and Psychological Sciences

Volume (5), Issue (33): 30 Sep 2021

P: 61 - 82

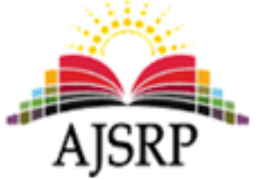

ISSN: 2522-3399
مجلة العلوم

التربوية والنفسية

المجلد (5)، العدد (33): 30 سبتمبر 2021 م

ص: 61 - 62 - n 82

\title{
The role of professional practices of primary school mathematics teachers in developing the skills of creative solution to mathematical problems among their students from the point of view of specialists
}

\author{
Muhannad Muhammad Al-Amary
}

Jeddah Education Department || Ministry of Education || KSA

\begin{abstract}
This study aimed to identify the role played by the professional practices done by Mathematics teachers at primary schools in the development of students' skills in solving Mathematics problems creatively from a professional point of view. In addition, the study aimed to identify any statistically significant differences in the professional practices according to some variants (job titles, years of experience, and qualifications). To achieve the objectives of the study, the researcher used the descriptive approach in surveys. A questionnaire has been designed as a tool to collect data. The questionnaire has been proved valid, reliable and practical when responded to by a sample included 80 Mathematics teachers and supervisors at Jeddah Directorate of Education (31) educational supervisors and (49) primary teachers. The questionnaire has been analyzed and statistically processed by SPSS. The research has formulated a list of professional practices done by Mathematics teachers at primary schools to develop students' creativity skills in solving Mathematics problems, which all were of equal high importance and came in a descending order in three axes: understanding the problem, execution planning, and generating ideas. Also, the study found that there are statistically significant differences in the responses in average for the job title (educational supervisor, teacher) variant concerning the role played by Mathematics teachers at primary schools in the development of students' skills in solving Mathematics problems creatively in all axes and in the questionnaire as whole. In addition, there is a statistically significant difference at $(\alpha \leq 0.05)$ between the averages of responses of professionals according to the qualifications and years of experience on the role played by Mathematics teachers at primary schools in the development of students' skills in solving Mathematics problems creatively for both the understanding problems and generating ideas axes. There are not any statistically significant differences in the execution and planning axis. Hence, the study set a model proposal for the roles to be played and practiced professionally by Mathematics teachers at primary schools to develop students' skills in solving Mathematics problems creatively. In the light of the study, the researcher introduced a set of recommendations and suggestions.
\end{abstract}

Keywords: Mathematics teachers - creativity skills in solving Mathematics problems, professional practices.

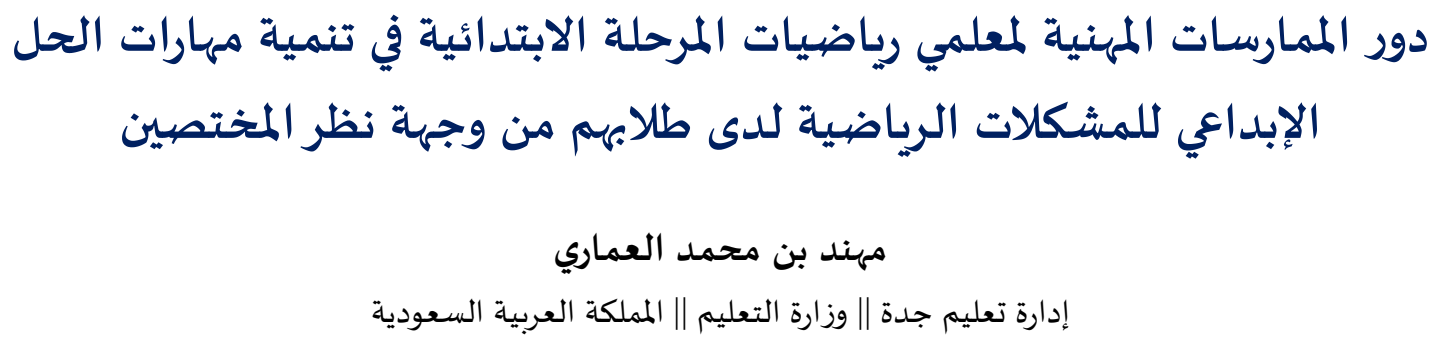


المستخلص: هدفت هذه الدراسة التعرف على دور الممارسات المهنية لمعلمي رياضيات المرحلة الابتدائية في تنمية مهارات الحل الإبداعي

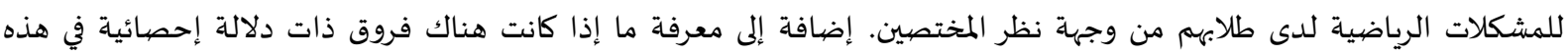

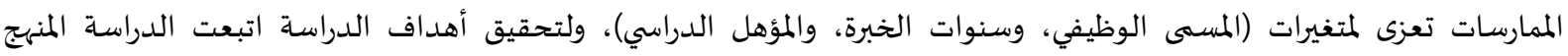

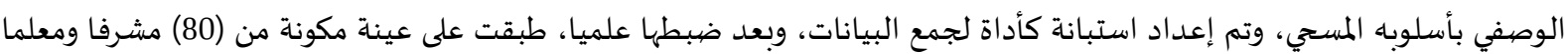

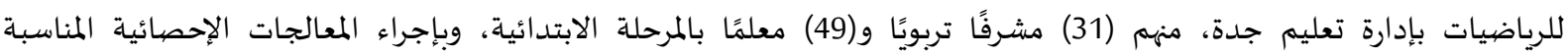

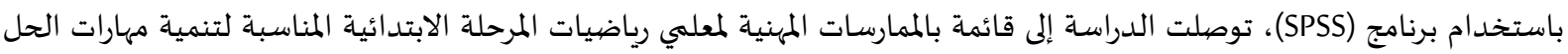

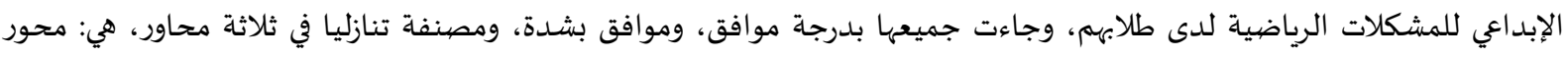

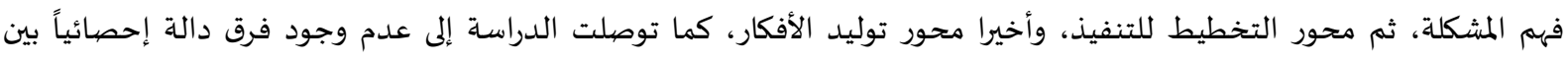

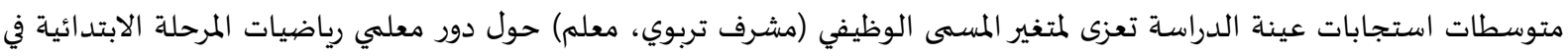

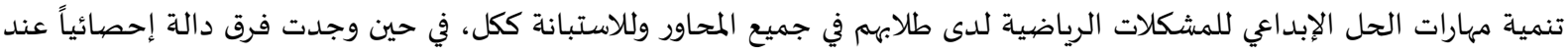

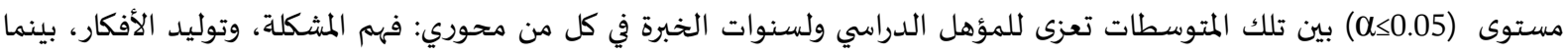

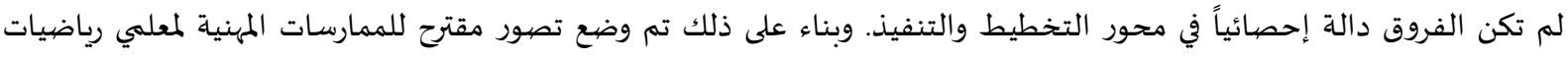

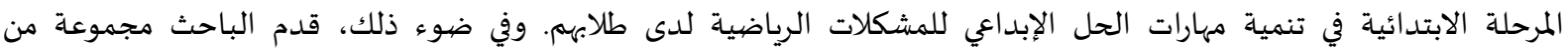
التوصيات والمقترحات.

الكلمات المفتاحية: معلمو الرياضيات -مهارات الحل الإبداعي للمشكلات الرياضية -الممارسات المهنية.

المقدمة.

ينظر إلى الرياضيات على أنها واحدة من أفضل الوسائل الخاصة التي تنهي مهارات التفكير لدى المتعلمين وفي

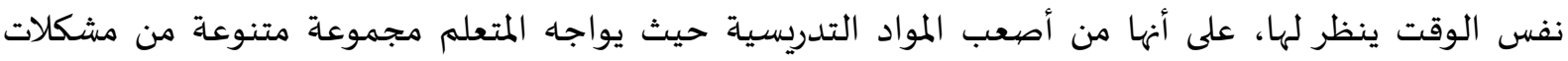

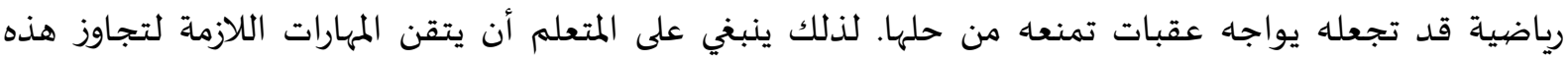

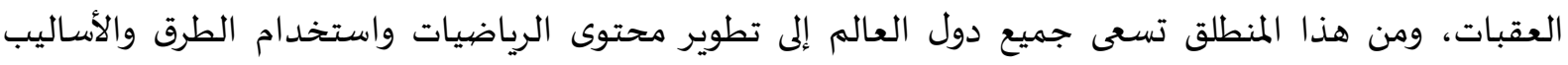

المناسبة لتدريسها.

ركزت رؤية المملكة العربية السعودية 2030 على أهمية بناء نظام يعزز من دور المعلم ويرفح تأهيله، سعياً

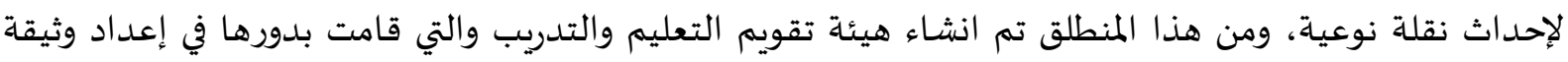

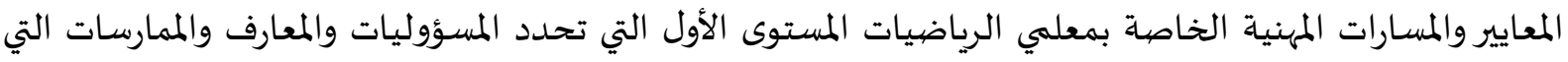

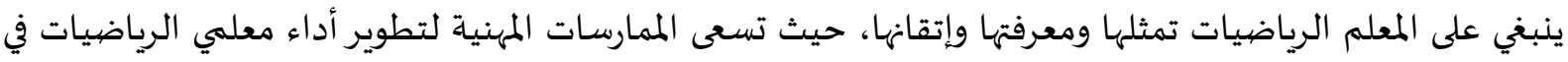

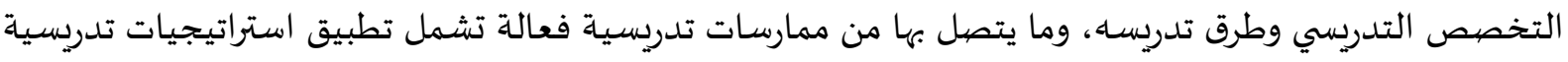

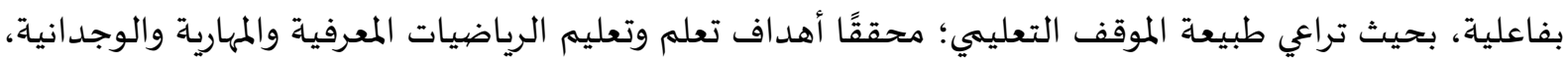
ومنظمًا لبيئة التعلم بحيث يظهر بوضوح دور المتعلم في التعلم (هيئة تقويم التعليم والتدريب، 2020). وقد قامت وزارة التعليم على مواءمة سلسلة عالمياة متميزة في مناهج الرياضيات، وهي سلسلة السئة ماجروهل

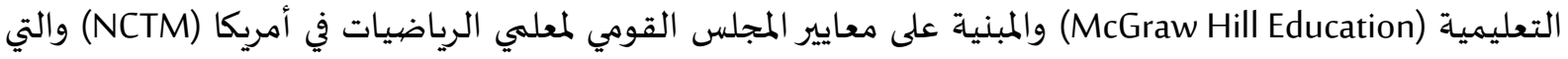

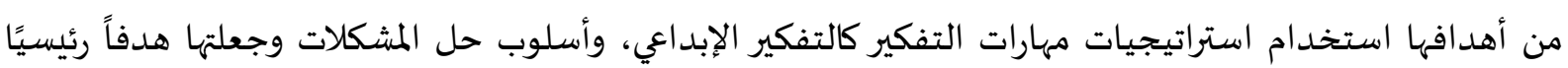

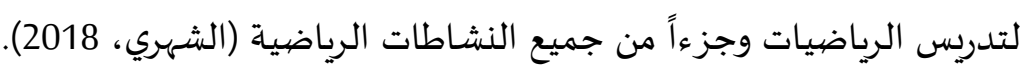

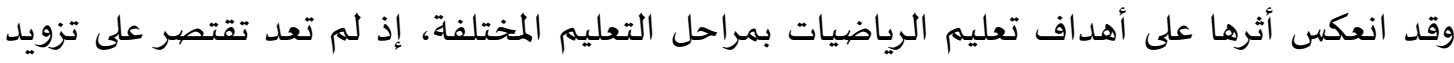

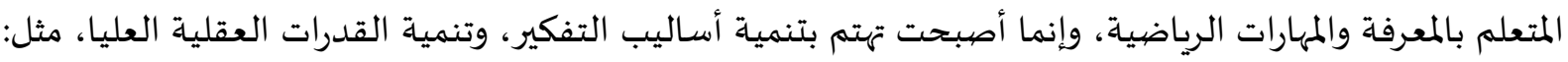

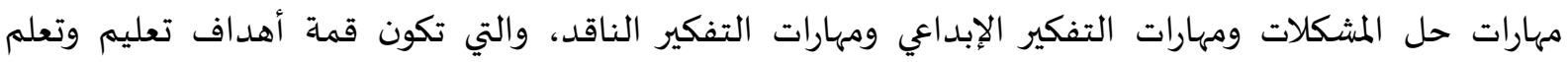
الرياضيات (هيئة تقويم التعليم والتدريب، 2019). 
وقد أشار مرجان (2018) أن الرياضيات كمادة تمثل مجالاً خصيبًا وغنيةٍ لتنمية قدرات الإبداع بصفة عامة

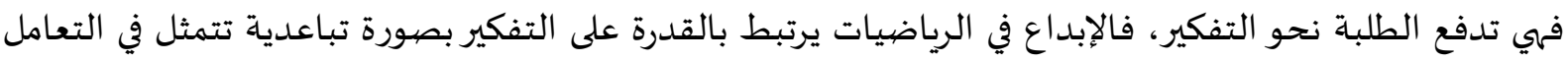

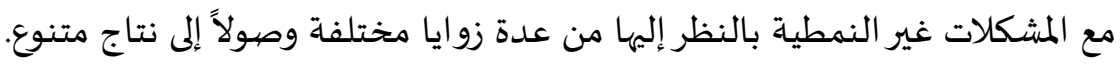

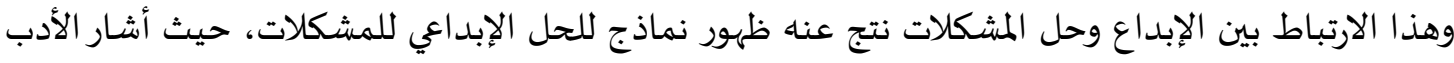

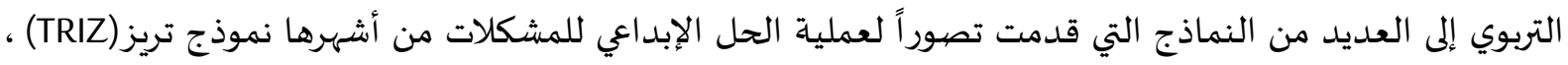

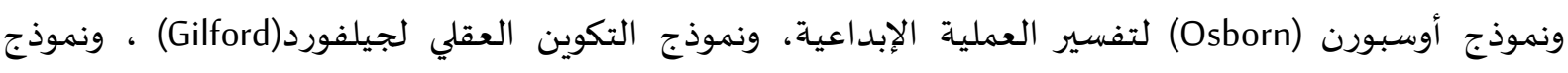
تورانس (Torrance) للمهارات الإبداعياة.

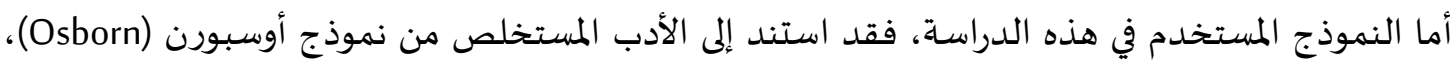

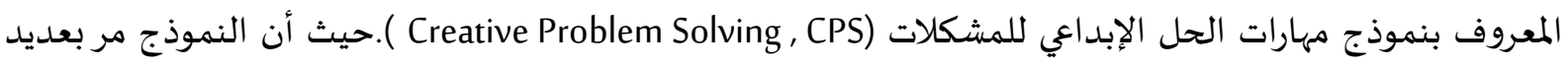
من مراحل التطوير حتى تبلور في آخر مرحلة لله في الإصدار السادس وهو نموذج تريفنجر وإزبكسن ( Treffinger \&

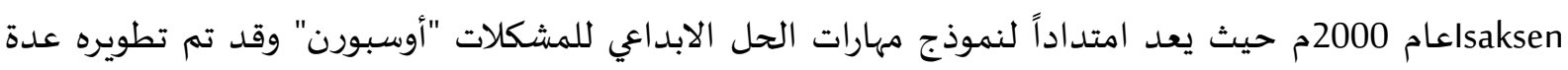
مرات إلى أن ظهر النموذج (CPS) (النعيمي، 2018). حيث أشـار الأعسر (2007) أن النموذج (CPS) يتكون من ثلاثنة عناصر رئيسية هي (فهم المشكلة، وتوليد

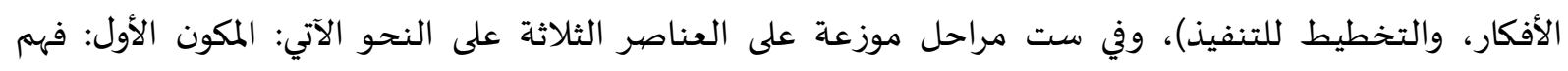

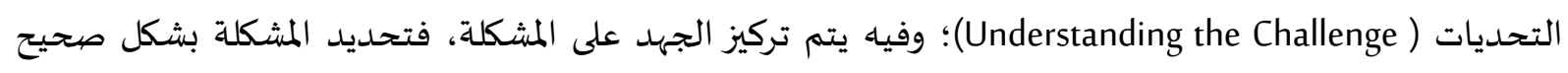

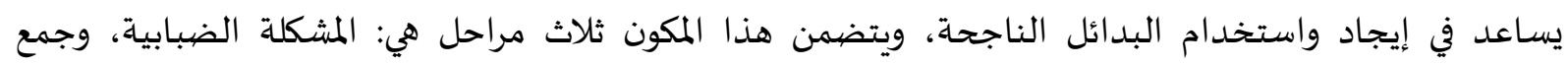

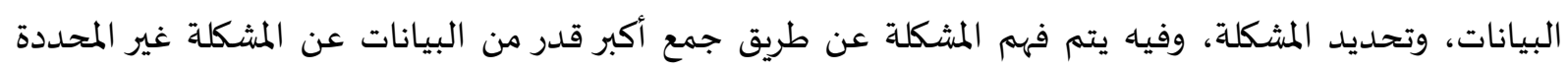

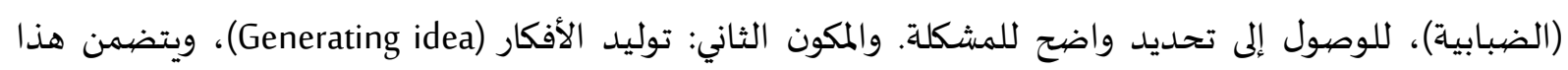

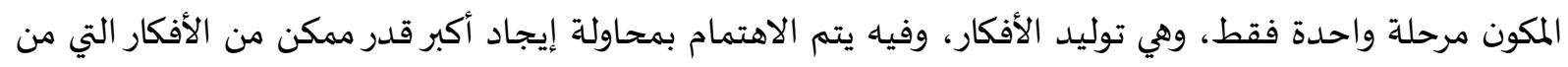

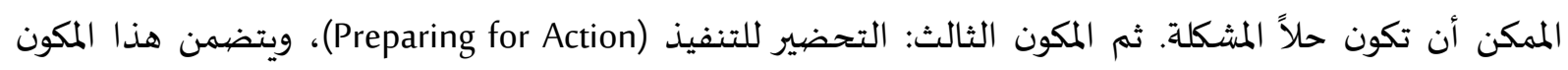
مرحلتين هما إيجاد الحلول، وإيجاد القبول والرضا عن الحلول، وفيه يتم تقييم أكثر الأفكار احتمالية لحل المشكلة المكلة التي تواجه الفرد.

حيث يتبع نموذج (CPS) مهارات الحل الإبداعي للمشكلات الأسلوب العلمي في التفكير، إذ أنه يقوم على إثارة دافعية الطلاب، وإشعارهم بالقلق إزاء وجود مشكلة لا يستطيعون حلها بسهولة، بعيداً عن الإلقائية

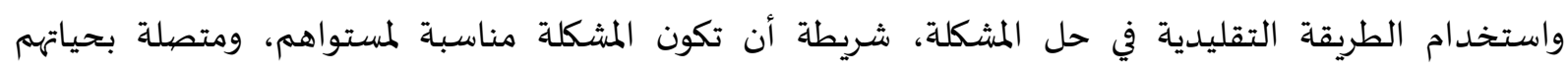
وخبراتهم التعليمية السابقة، وذات صلة بموضوات التةلية الدرس (عقيلان، 2015).

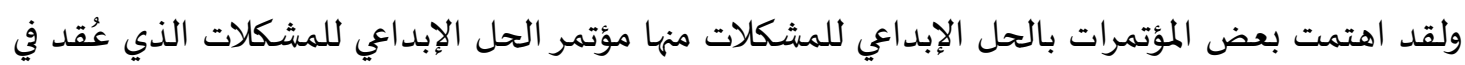

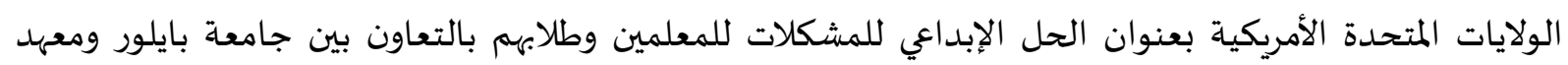

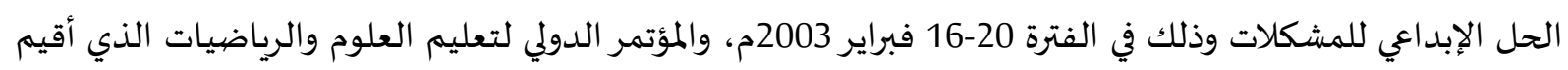

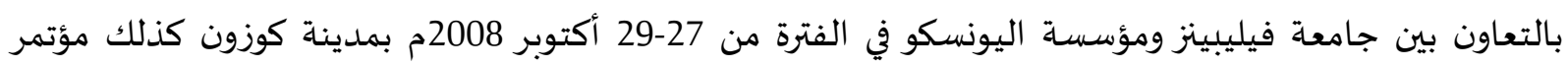
الحل الإبداعي للمشكلات الذي عقد عام 2010م في أمريكا تحت رعاية معهد الحل الإبداعي للمشكلات (البنا،

ويعد حل المشكلات إبداعيا من أبرز أهداف تدريس مادة الرياضيات، كونها تحتوي على كثير من المهارات

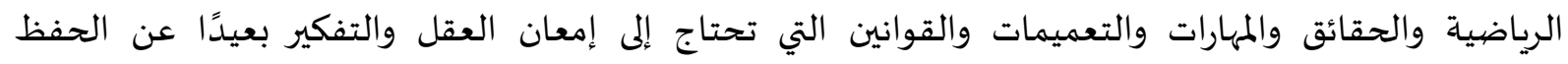
والاستظهار الذي يضعف المعرفة مع مرور الوقت (الصلاحيين والخوالدة، 2017). 
كما أشارت بعض من الأدبيات والدراسات السابقة (لافي، 2013؛ حسن، 2017؛ التونسي، 2019) إلى أهمية

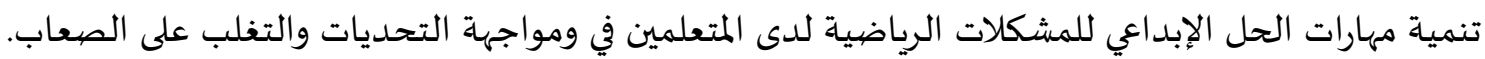

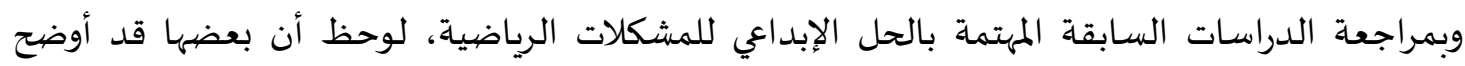

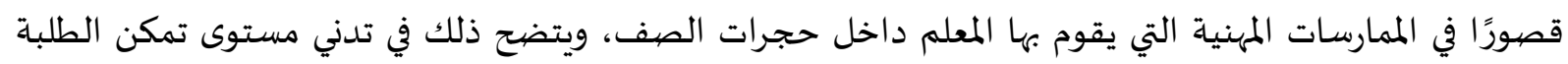

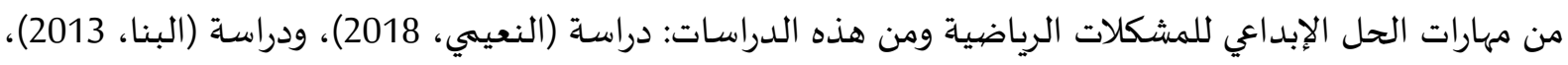
ودراسة (حسن.2017) منارت وتؤكد عديد من الدراسات السابقة على وجود فعالية في استخدام نموذج ( CPS) مهارات الحل الإبداعي

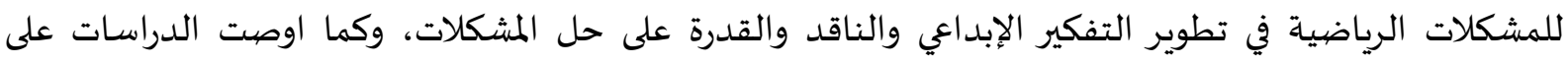

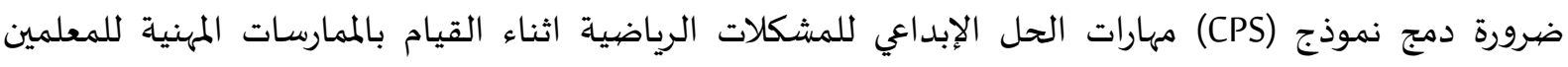

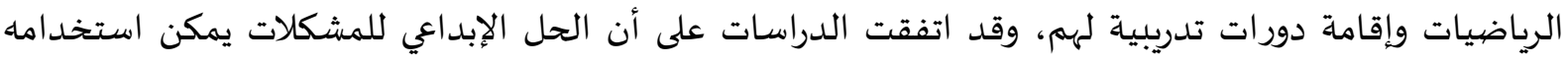

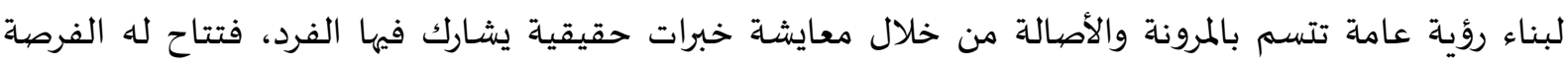

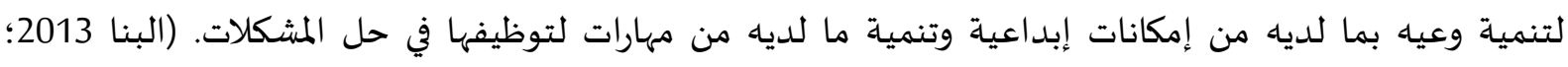

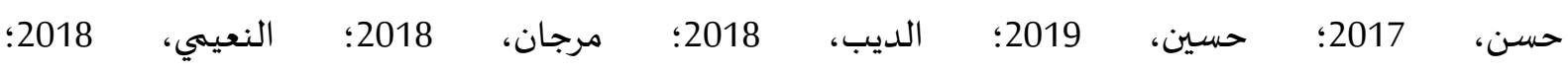
A Muin, et al 2018 هو وآخرون (Hu, et al , 2017)؛

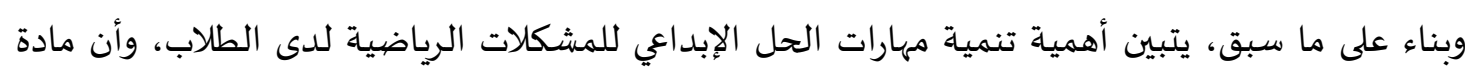

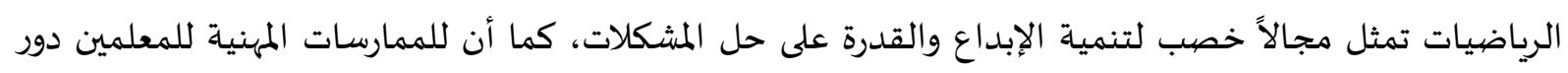

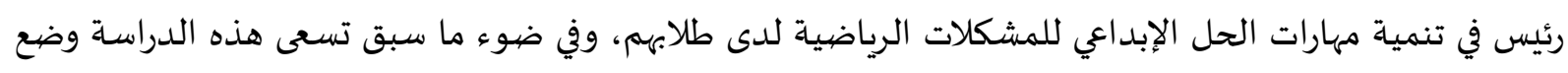

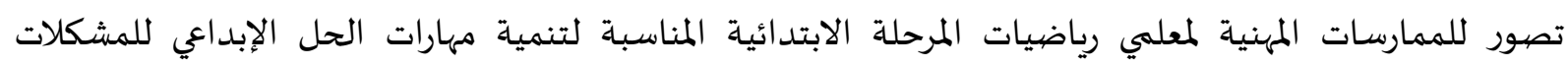
الرياضية لدى طلابهم في ضوء آراء المتخصصين.

مشكلة الدراسة:

نبع الشعور بالمشكلة لدى الباحث من خلال نتائج الاختبارات العالمية للرياضيات والعلوم (TIMSS) التي

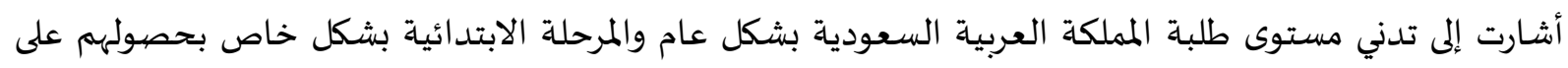

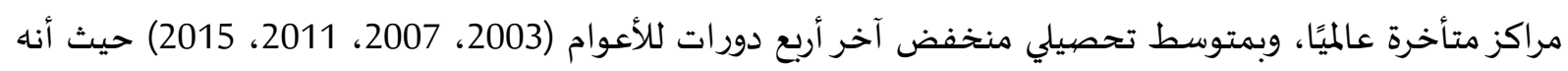

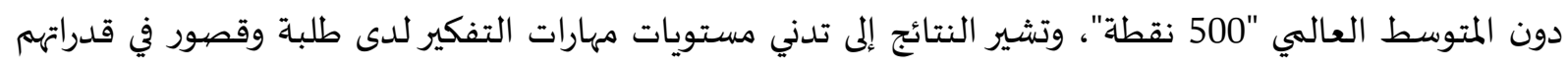

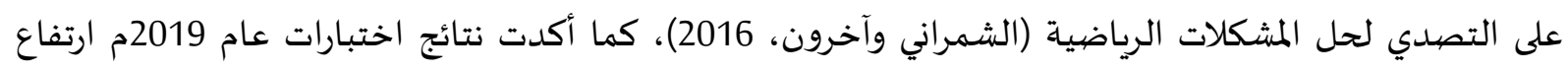

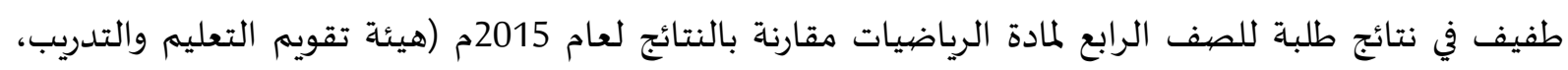

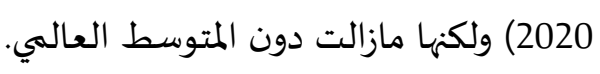
وتجدر الإشارة إلى أن اختبارات TIMSS تعتمد على أدوات أخرى منها الاستبانة والتي تمس القضايا التربوية

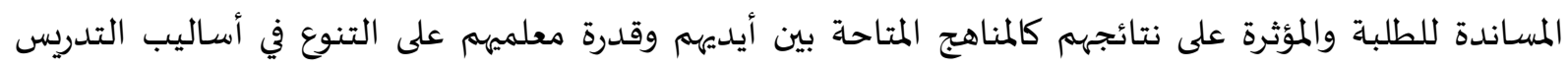

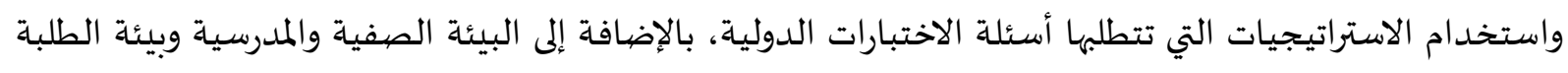

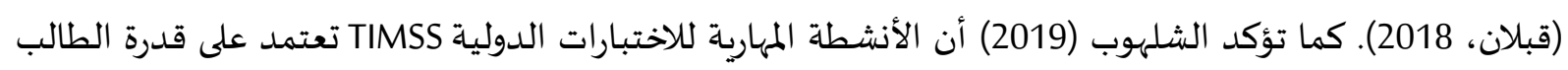
على حل المشكلات الرياضية بطرق إبداعية. وتأسيساً على ما سبق، وبالتزامن مع إطلاق هيئة تقويم التعليم والتدريب وثيقة المعايير والمسارات المهنية الماتية

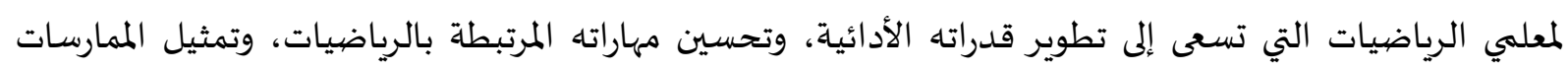


والسلوكيات الفعالة، والعمل على استخدام استراتيجيات حديثة، وتحقيق أهداف تعلم وتعليم الرياضيات (المعرفية،

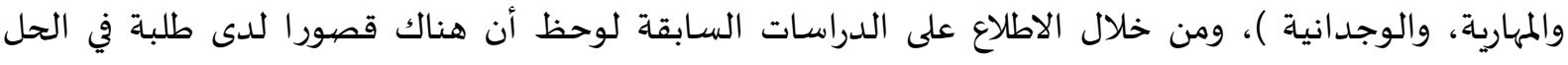

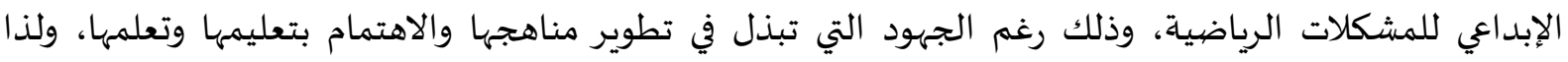

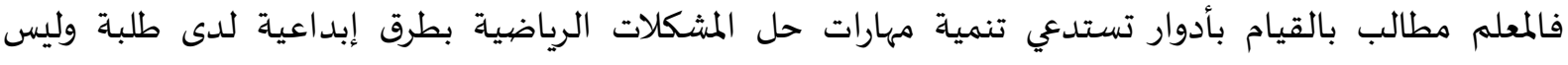

بالطرائق تقليدية.

ومن خلال عمل الباحث معلما للرياضيات في المرحلة الابتدائية، لوحظ انخفاض مستوى الطلاب في حل

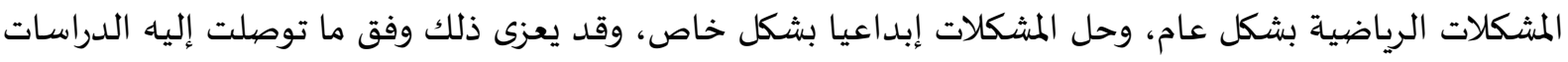

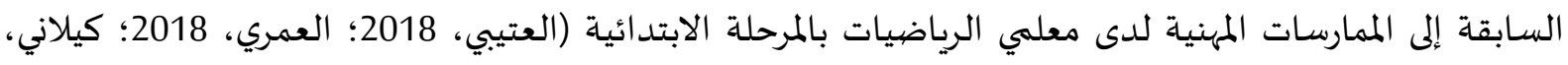

2017؛ المالكي، 2018).

\section{أسئلة الدراسـة:}

وبناء على ما سبق فقد حددت مشكلة الدراسة بالسؤال الرئيسي التالي: ما الممارسات المهنية لمعلمي

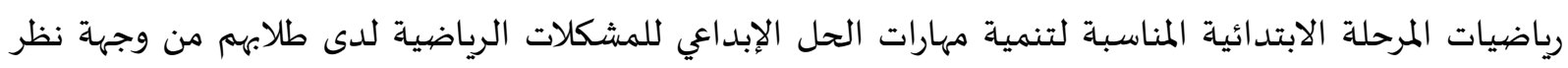
المختصين؟ وينبثق عنه التساؤلات الفرعية التالية: 1- ما الممارسات المهنية لمعلمي رياضيات المرحلة الابتدائية المناسبة لتنمية مهارات فهم المشكلة الرياضية لدى لماتيات طلابهم؟ 2- ما الممارسات المهنية لمعلمي رياضيات المرحلة الابتدائية المناسبة لتنمية مهارات توليد الأفكار لحل المشكلة

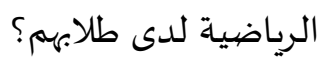

3- ما الممارسات المهنية لمعلمي رياضيات المرحلة الابتدائية المناسبة لتنمية مهارات التخطيط لتنفيذ حل المشكلة

$$
\text { الرياضية لدى طلابهم؟ }
$$

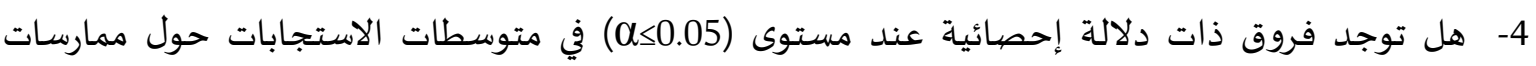

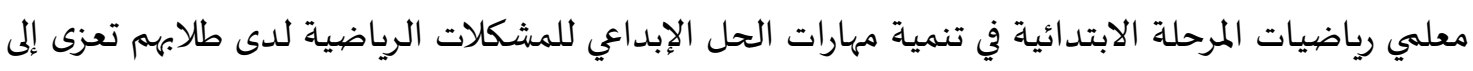

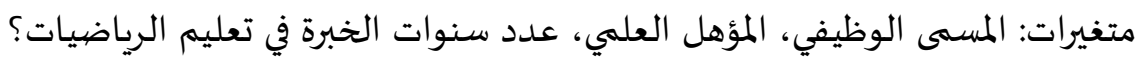

سعت هذه الدراسة إلى تحقيق الأهداف التالية: 1- تعرف الممارسات المهنية لمعلمي رياضيات المرحلة الابتدائية المناسبة لتنمية مهارات فهم المشكلة الرياضية لدى طلابهم. 2- تعرف الممارسات المهنية لمعلمي رياضيات المرحلة الابتدائية المناسبة لتنمية مهارات توليد الأفكار لحل المشكلة الرياضية لدى طلابهم. 3- تعرف الممارسات المهنية لمعلمي رياضيات المرحلة الابتدائية المناسبة لتنمية مهارات التخطيط لتنفيذ حل المشكلة الرياضية لدى طلابهم.

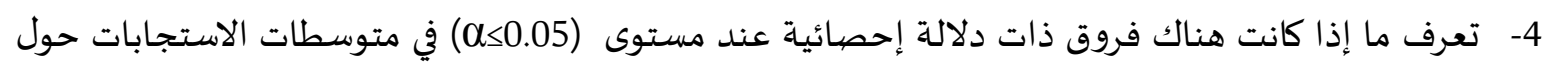

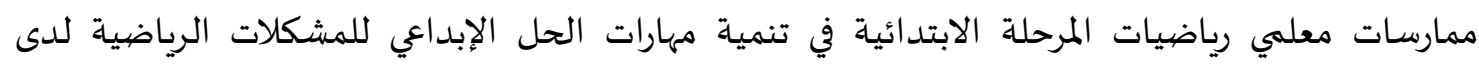

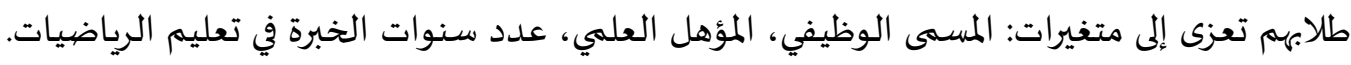


تتمثل أهمية الدراسة الحالية فيما يلي:

- تزويد معلمي الرياضيات بقائمة تتضمن الممارسات المهنية اللازمة لتنمية مهارات الحل الإبداعي للمشكلات الرياضية لدى طلابهم.

تقدم الدراسة تصورا مقترحا للممارسات المهنية اللازمة لتنمية مهارات الحل الإبداعي للمشكلات الرياضية

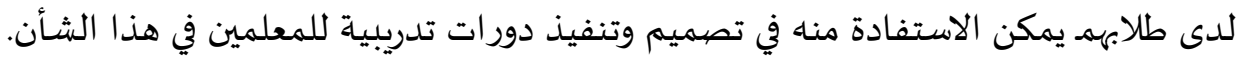
إثراء المعرفة والبحث العلمي في مجال تنمية مهارات الحل الإبداعي للمشكلات الرياضية، والمهمارسات التدريسية اللازمة لمعلمي الرياضيات. - تأتي هذه الدراسة استجابة لتوصيات كثير من المؤتمرات التربوية والمؤتمرات الدولية لتعليم العلوم والرياضيات والأبحاث والدراسات العلمية حول فاعلية تطبيق مهارات الحل الإبداعي للمشكلات الرياضية.

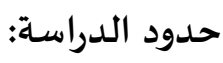
تقتصر حدود الدراسة الحالية على: الحدود الموضوعية: الكشف عن الممارسات المهنية لمعلمي رياضيات المرحلة الابتدائية المناسبة لتنمية مهارات الحل الإبداعي للمشكلات الرياضية لدى طلابهم وفق نموذج (CPS).

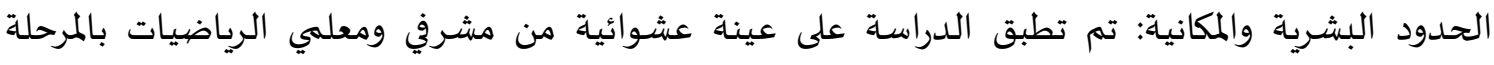
الابتدائية التابعين لإدارة تعليم جدة.

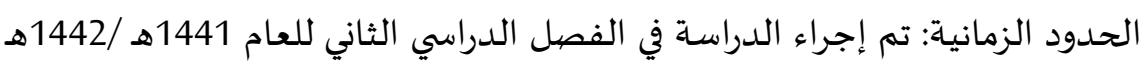

$$
\text { مصطلحات الدراسـة: }
$$

- الممارسات المهنية لمعلمي الرياضيات: عرفتها هيئة تقويم التعليم والتدريب "هي ما ينبغي لمعلمي الرياضيات

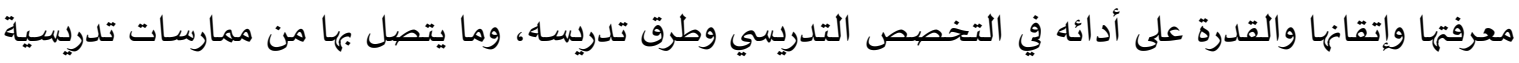

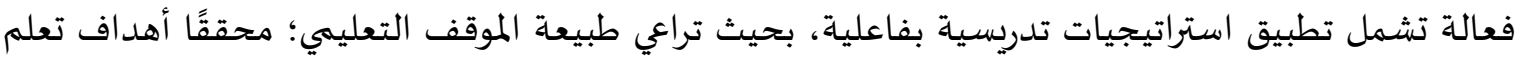

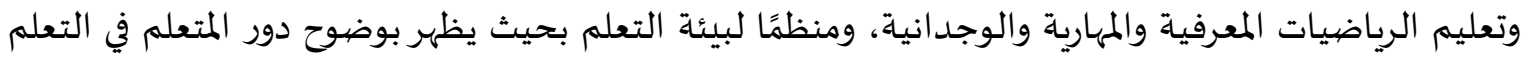
مراعياً عناصر الخطة وخصائص الطلاب " (2020، 6ماضيات O ويعرفها الباحث إجرائيًا بأها: الممارسات المهنية التي اعتمدتها هيئة تقويم التعليم والتدريب للعام 2020م التي

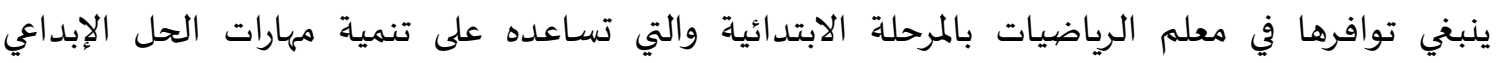

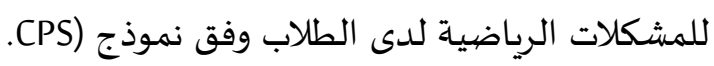

- مهارات الحل الإبداعي للمشكلات الرياضية: عرف حسن مهارات الحل الإبداعي للمشكلات الرياضية بأنانه:

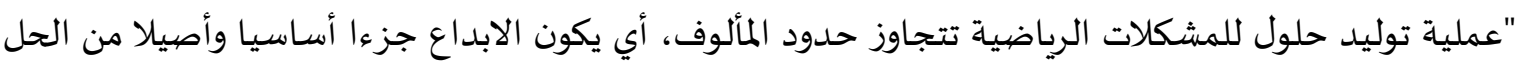

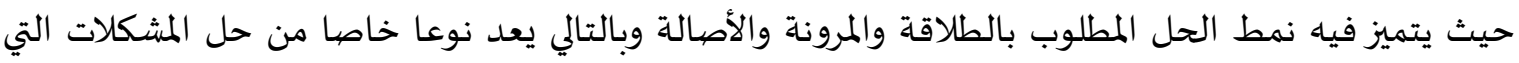

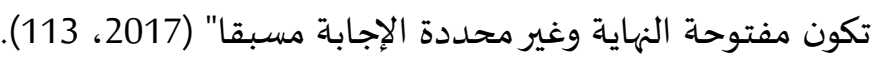

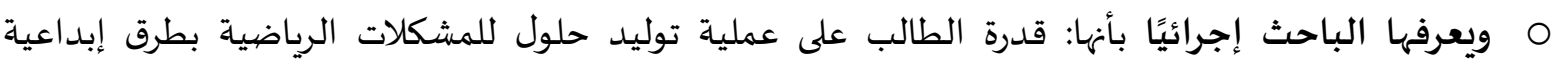

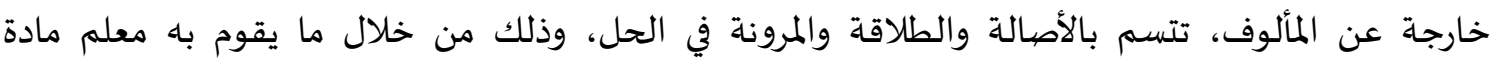


الرياضيات في المرحلة الابتدائية من توظيف للممارسات المهنية وتوجيها في سبيل تنمية الحل الابداعي للمشكلات الرياضية لدى الطلاب.

2- 20 - 20هجية الدراسـة وإجراءاتها.

أولاً: منهج البحث

في ضوء طبيعة البحث وأهدافه، تم استخدام المنهج الوصفي بأسلوبه المستي (Descriptive Approach in Survey Method" ظاهرة أو مشكلة محددة، وتصويرها كميًا عن طريق جمع بيانات ومعلومات مقننة عن الظاهرة أو المشكلة، وتصنيفها وتحليلها وإخضاعها للدراسة الدقيقة.

ثانياً: متجتمع الدراسة تألف مجتمع البحث من كافة مشرفي ومعلمي الرياضيات بالمرحلة الابتدائية التابعين لإدارة ومكاتب التعليم بجدة، ممن لازالوا على رأس العمل خلال العام الدراسي (1442/1441هـ).

ثالثاً: عينة الدراسة فيما يخص المشرفين التربويين تم اختيار جميع المشرفين التربويين في إدارة ومكاتب تعليم جدة الذين لازالوا

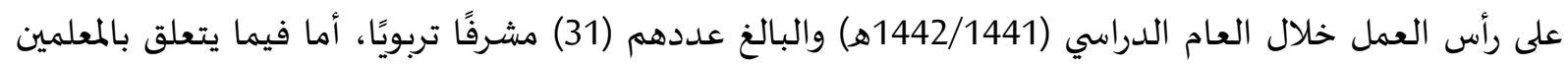

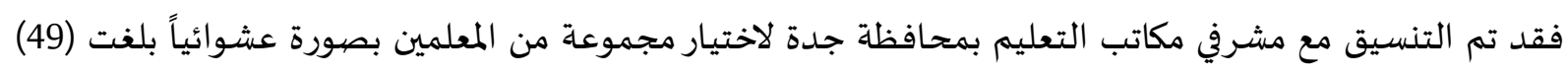
معلما، وبتطبيق الاستبانة إلكترونيا تم الحصول على (80) استجابة مكتملة وصالحة مئلة للتحليل، تمثل استجابة (31) مشرفًا تربويًا، (49) معلمًا. معلمان. أداة الدراسة وإجراءات بنائها: لتحقيق أهداف البحث والإجابة عن تساؤلاته، وقع الاختيار على الاستبانة كأداة لجمع البيانات، إذان تعد إندان

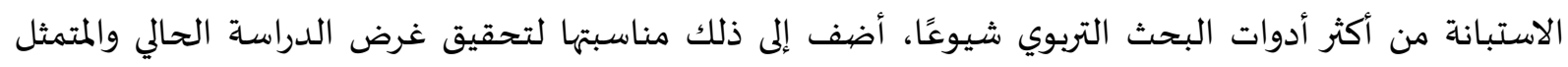

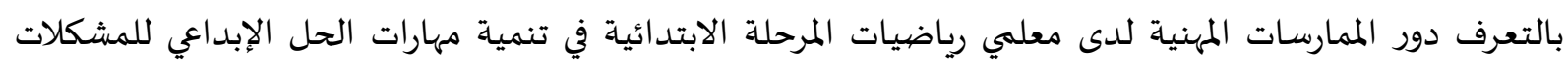
الرياضية لدى طلابهم من وجهة نظر المختصين، موزعة على وفق ثلاثة محاور كالتالي:

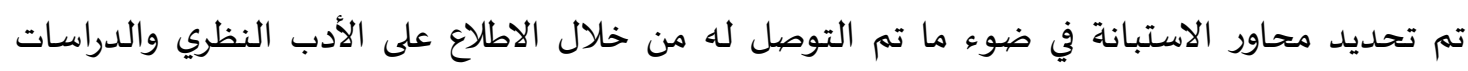

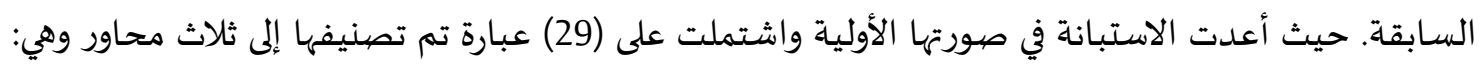

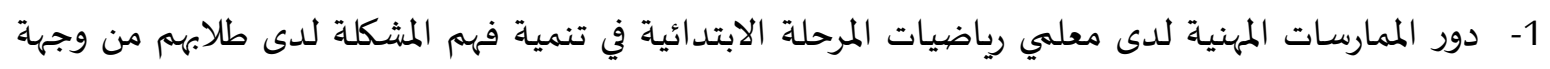
نظر المختصين، حيث تألف هذا المحور من (10) فقرات. 2- دور الممارسات المهنية لدى معلمي رياضيات المرحلة الابتدائية في تنمية توليد الأفكار لدى طاتلاتهم من وجهات نظر المختصين، حيث تألف هذا المحور من (8) فقرات. 3- دور الممارسات المهنية لدى معلمي رياضيات المرحلة الابتدائية في تنمية التخطيط والتنفيذ لدى طاتى طلابهم من وجهة نظر المختصين، حيث تألف هذا المحور من (11) فقرة. 
صددق الاتساق الداخلي لفقرات الاستبانة: طبقت الاستبانة على (32) من أفراد مجتمع البحث (من خارج

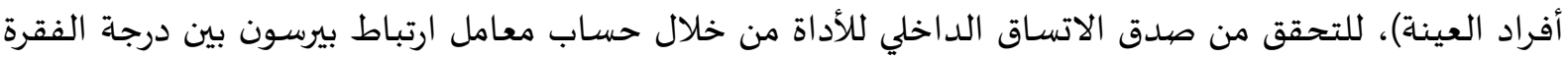

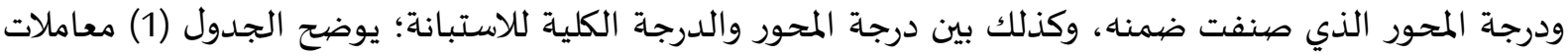
الارتباط بين درجات الفقرات ودرجة المحور التي صنفت ضمنه وكذلك معاملات الارتباط بين درجات المحاور والدرجة

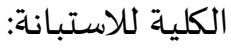

جدول (1): معاملات الارتباط لفقرات الاستبانة مع درجة المحور ودرجة المحور مع الدرجة الكلية

\begin{tabular}{|c|c|c|c|c|c|}
\hline \multicolumn{2}{|c|}{ فقرات المحو الثالث: التخطيط والتنفيذ } & \multicolumn{2}{|c|}{ فقرات المحور الثاني: توليد } & \multicolumn{2}{|c|}{ فقرات المحور الأول: فهم } \\
\hline $0.80^{* *}$ & 1 & $0.81^{* *}$ & 1 & $0.73^{* *}$ & 1 \\
\hline $0.77^{* *}$ & 2 & $0.82^{* *}$ & 2 & $0.72^{* *}$ & 2 \\
\hline $0.79^{* *}$ & 3 & $0.70^{* *}$ & 3 & $0.74 * *$ & 3 \\
\hline $0.74^{* *}$ & 4 & $0.85^{* *}$ & 4 & $0.81^{* *}$ & 4 \\
\hline $0.80^{* *}$ & 5 & $0.71^{* *}$ & 5 & $0.67^{* *}$ & 5 \\
\hline $0.81^{* *}$ & 6 & $0.82^{* *}$ & 6 & $0.81^{* *}$ & 6 \\
\hline $0.77^{* *}$ & 7 & $0.84^{* *}$ & 7 & $0.75^{* *}$ & 7 \\
\hline $0.84^{* *}$ & 8 & $0.84 * *$ & 8 & $0.77^{* *}$ & 8 \\
\hline $0.73^{* *}$ & 9 & \multirow{4}{*}{$0.95^{* *}$} & \multirow{4}{*}{ المحور مع الدرجة } & $0.72^{* *}$ & 9 \\
\hline $0.68^{* *}$ & 10 & & & $0.72^{* *}$ & 10 \\
\hline $0.69^{* *}$ & 11 & & & & المحور مع \\
\hline $0.95^{* *}$ & الدرجة الكلية المحور مع & & & $0.94^{* *}$ & الدرجة الكلية \\
\hline & & دلالة & ** دال عـ & & \\
\hline
\end{tabular}

ثبات الاستبانة

بعد تطبيق الاستبانة على العينة الاستطلاعية، تم حساب ثبات الاستبانة بطريقة تحليل التباين باستخدام معامل ثبات ألفا كرونباخ، والجدول (2) يوضح النتائج التي حصلنا عليها:

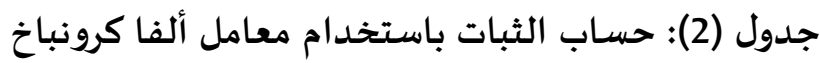

\begin{tabular}{|c|c|c|}
\hline معامل ثبات الفا كرونباخ & محاور الاستبانة & ค \\
\hline 0.91 & فهم المشكلة & 1 \\
\hline 0.92 & توليد الأفكار & 2 \\
\hline 0.93 & التخطيط والتنفيذ & 3 \\
\hline 0.97 & ل ل أداة ككل & \\
\hline
\end{tabular}

تشير معاملات الثبات في جدول (2) أن الاستبانة تتمتع بدرجة ثبات عالية، تجعل منها صالحة لأغراض

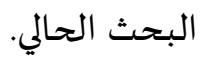


إجراءات تنفيذ الدراسة: تم اتباع الإجراءات الآتية لتنفيذ البحث:

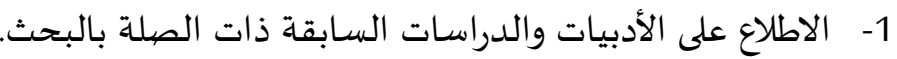

2- - حصر مجتمع البحث واختيار العينة.

3- إعداد أداة البحث (الاستبانة).

4- التحقق من مؤشرات الصدق والثبات للاستبانة.

5- إرسال استبانة إلكترونيا على عينة البحث من خلال المشرفين التربويين بقسم الرياضيات بإدارة ومكاتب تعليم

6- تجميع البيانات وحصرها بعد مرور (30) يومًا من تاريخ توزيع الاستبانة.

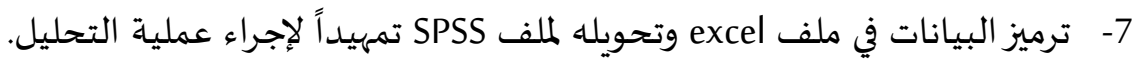

8- إجراء عملية التحليل وعرض وتنظيم النتائج والإجابة عن الأسئلة ومناقشتها.

9- تقديم التوصيات والمقترحات في ضوء النتائج التي تم التوصل لها.

الأساليب الإحصائية المستخدمة:

تمت عملية التحليل والمعالجة الإحصائية باستخدام برنامج الرزم الإحصائية (SPSS) وفقاً للأساليب الآتية:

- مercentages, Means and Standard Deviations) النسب المئوية والمتوسطات والانحرافات المعيارية

لوصف خصائص العينة وكذلك التعرف درجة استجابات العينة على فقرات الاستبانة.

- معامل ارتباط بيرسون (Pearson Correlation Coefficient) للتعرف على صدق الاتساق الداخلي للاستبانة

من خلال حساب معامل الارتباط بين درجة الفقرة ودرجة المحور وكذلك بين درجة المحور والدرجة الكلية.

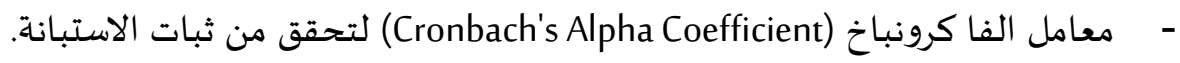

- اختبار كولمنجروف سميرنوف (Kolmogorov- Smirnov Test) للتحقق من تحقق شرط اعتدالية التوزيع

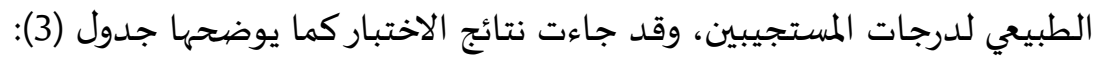

جدول(3): اختبار كولمنجروف سميرنوف (Kolmogorov- Smirnov Test) لتحقق من اعتدالية التوزيع للبيانات

\begin{tabular}{|c|c|c|c|}
\hline \multicolumn{2}{|c|}{ Kolmogorov- Smirnov } & \multirow{2}{*}{ درجة الحرية df } & \multirow{2}{*}{ مدحاور الاستبانة } \\
\hline Sig & Statistic & & \\
\hline 0.000 & 0.148 & 80 & المحور الأول: فهم المشكلة \\
\hline 0.022 & 0.108 & 80 & المحور الثاني: توليد الأفكار \\
\hline 0.019 & 0.088 & 80 & المحور الثالث: التخطيط والتنفيذ \\
\hline
\end{tabular}

توضيح النتائج في جدول (3) الدلالة الإحصائية لاختبار Kolmogorov- Smirnov لمحاور الاستبانة، حيث التاني

تظهر النتائج أن بيانات المحور الأول والثاني والثالث لا تتبع التوزيع الطبيعي، وعليه يستخدم في هذه الحتبار لإلآلة الإحصاء

اللامعلمي.

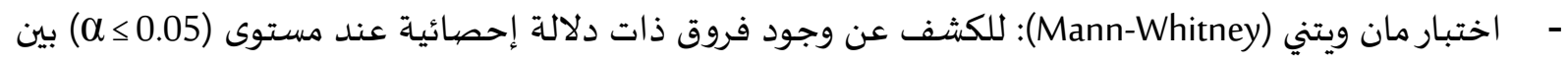

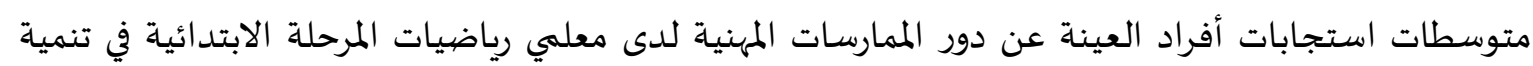
مهارات الحل الإبداعي للمشكلات الرياضية وفقاً للمسمى الوظيفي (معلم، مشرف تربوي)، وكذلك وفقاً للمؤهل العلمي (بكالوريوس، ماجستير). 
- اختبار كروسكال والس(Kruskal-wallis) : للكشف عن وجود فروق ذات دلالة إحصائية عند مستوى >

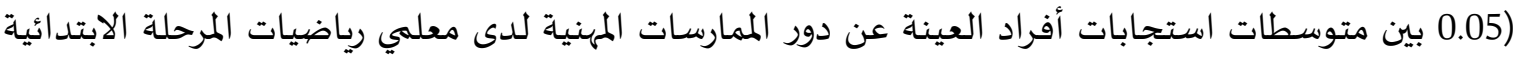

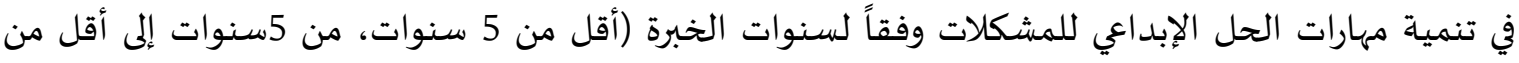
10 سنوات، من 10 سنوات إلى أقل من 15 سنة، 15 سنة فأكثر).

3- عرض نتائج الدراسـة ومناقشتها.

عرض نتائج السؤال الرئيسي: "ما الممارسات المهنية لمعلمي رياضيات المرحلة الابتدائية في تنمية مهارات

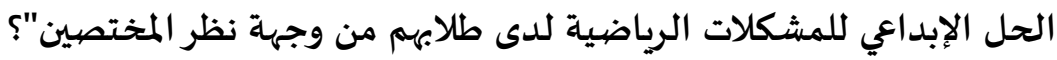

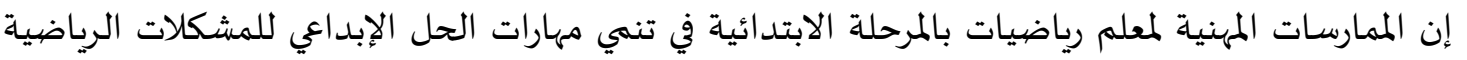

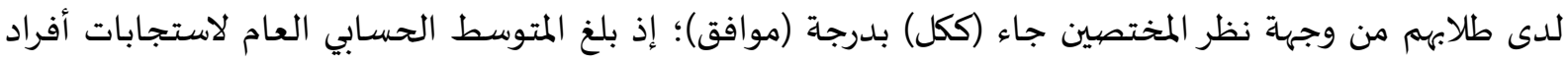

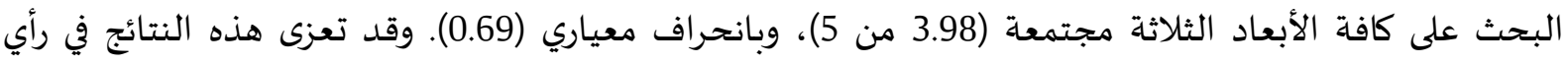
الباحث إلى إدراك أفراد البحث من المشرفي ومعلمي الرياضيات بإدارة ومدارس تعليم جدة، لأهمية الأدوار المناطة

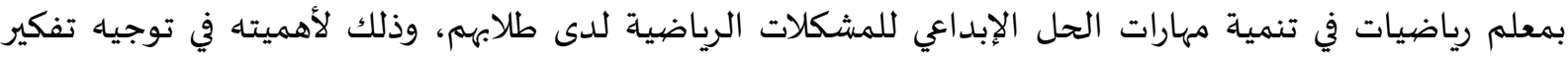
المتعلمين نحو حل المشكلة وإعادة صياغتها بالطرق التي تناسب تفكيرهم والقدرة على انتقاء المعلومات الرياضية

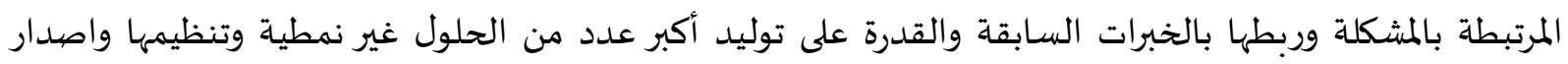

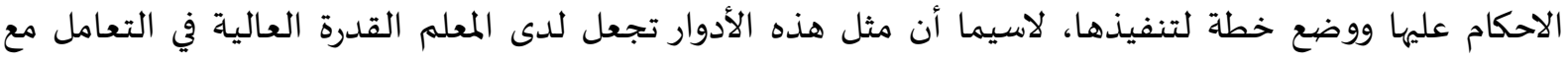

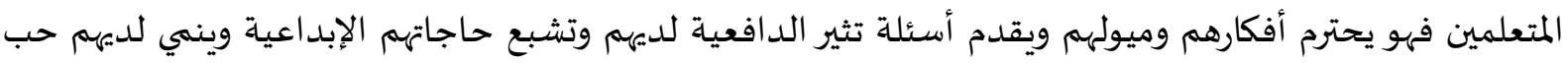

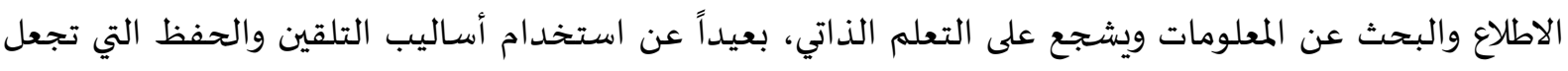
المتعلم في محور الاستقبال المعلومة بدلاً عن البحث عنها.

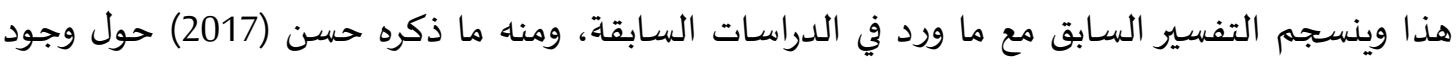
علاقة طردية بين فاعلية دور المعلمين الذين خضعوا للبرنامج تدريبي حول الكفاءة الذاتية وتنمية مهارات الحل

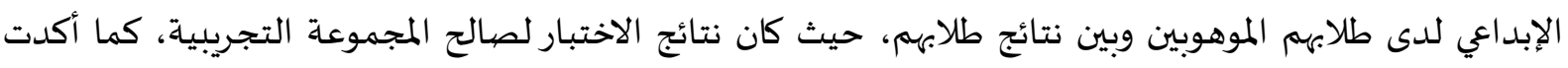

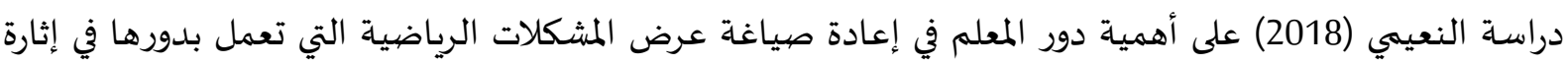
تفكير وخلق روح التحدي لدى الطلاب تلفت انتباههم وتعمق تركيزهم.. وتتشابه هذه النتائج مع ما توصلت إليه العديد من الدراسات السابقة، ومنها دراسة (حسين، 2019) على تردئ

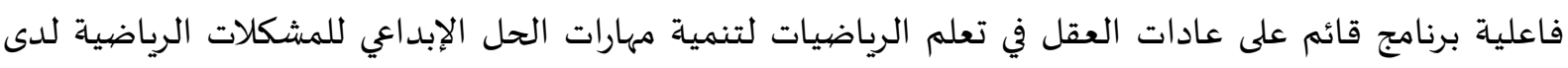

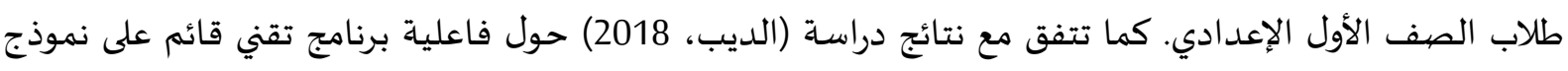

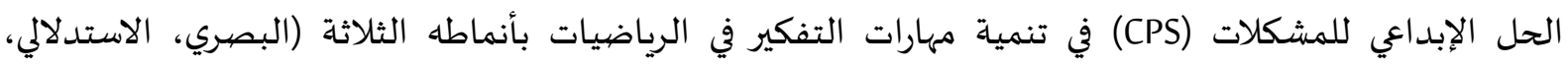

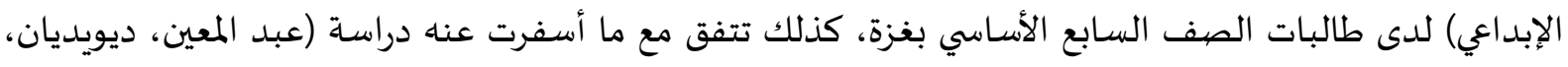
2018) إلى تحليل أثر استخدام نموذج الحل الإبداعي للمشكلات على التفكير الرياضي.

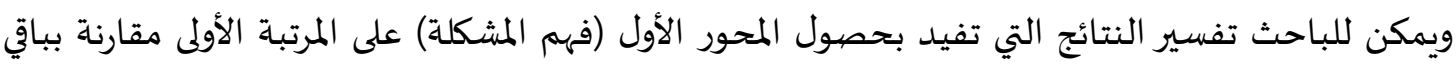

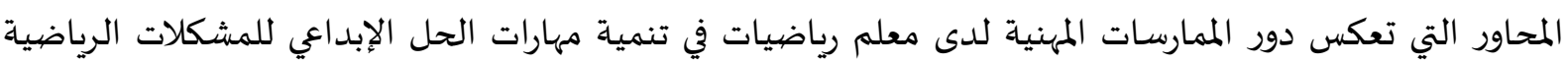

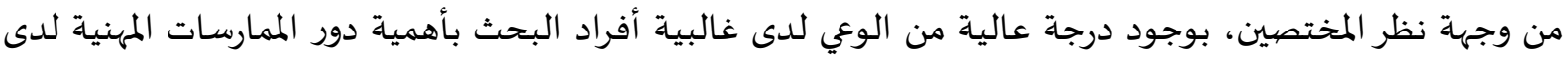

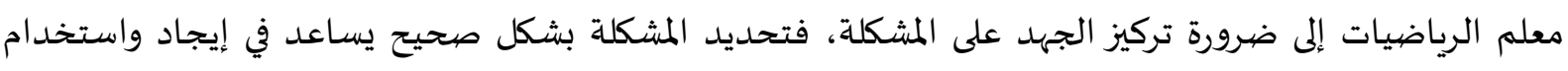


البدائل الناجحة، وذلك بوصفه الدور الأساس والخطوة الأولى في إنجاح مهارات الحل الإبداعي، والذي ينبغي أن يأتي

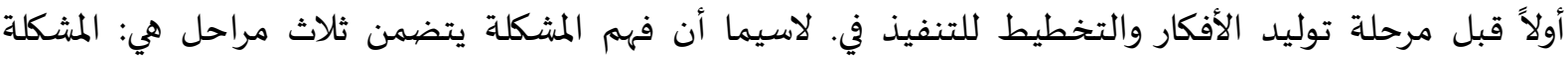

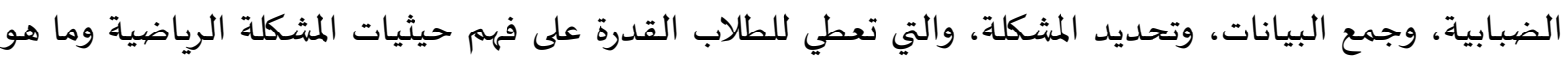

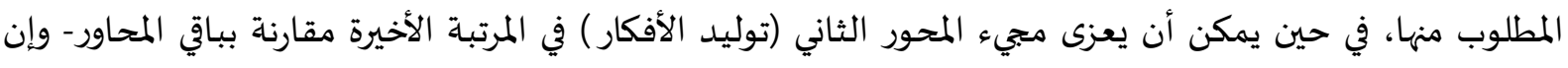

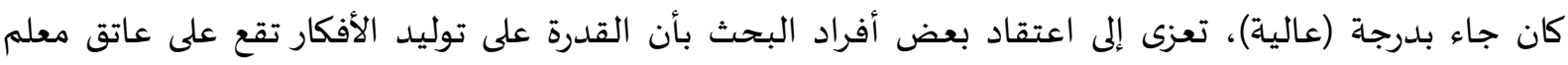

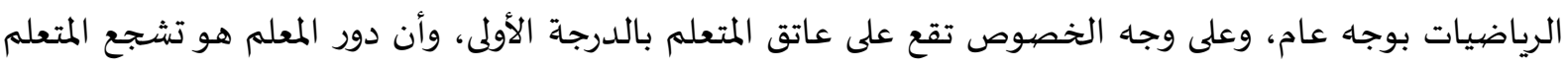

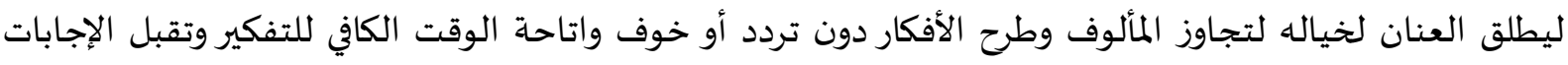

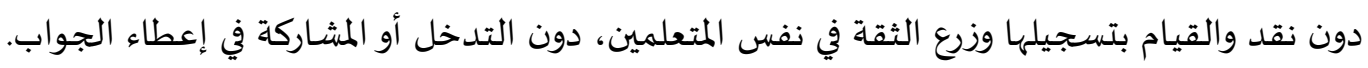

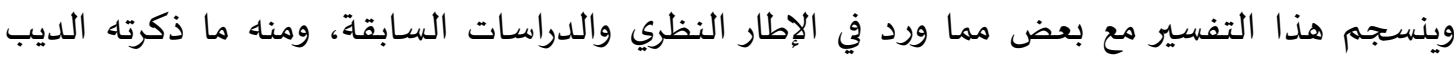

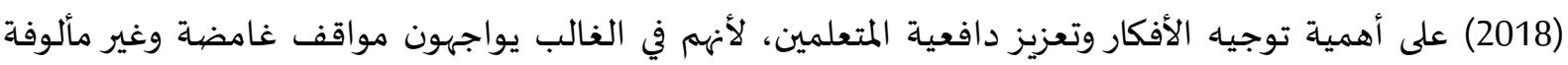
تحتاج إلى طرح الأفكار بكل حرية ودون تردد. وقد أشار عقيلان (2015) على أهمية دور المعلم في تفعيل الأنشطة الأنس

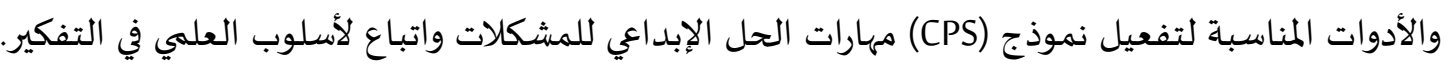

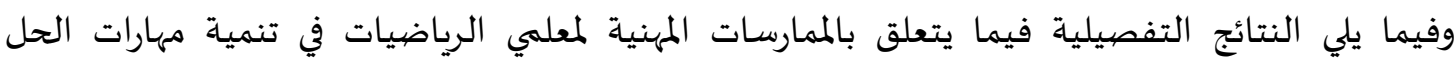

الإبداعي للمشكلات الرياضية لدى طلايهم من وجهة نظر المختصين:

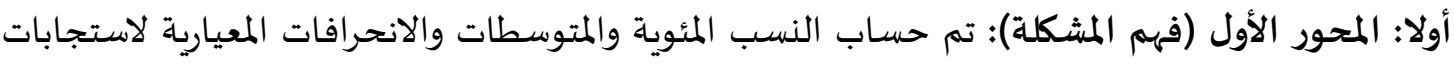
المختصين عن كل فقرة من فقرات فهم المشكلة، والجدول (4) يوضح النتائج التي حصلنا عليها: الجدول (4): النسب المئوية والمتوسطات والانحرافات المعيارية لفقرات فهم المشكلة مرتبة تنازليا

\begin{tabular}{|c|c|c|c|c|c|c|c|c|c|}
\hline$\overline{3}$ & $\begin{array}{l}\overline{\bar{j}} \\
\bar{\sigma} \\
\xi \\
\text { के }\end{array}$ & बु. & 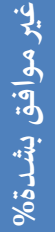 & $\begin{array}{l}\frac{y}{2} \\
\frac{2}{2} \\
g^{2}\end{array}$ & $\frac{3}{7}$ & $\frac{2}{2 \%}$ & 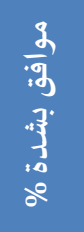 & فقرات فهم المشكلة & $\hat{\imath}$ \\
\hline 1 & 0.81 & 4.23 & 0 & 2.5 & 16.3 & 37.5 & 43.8 & يعمل على تهيئة بيئة تعليمية تفاعلية. & 2 \\
\hline 2 & 0.79 & 4.20 & $\mathbf{0}$ & 2.5 & 15 & 42.5 & 40 & 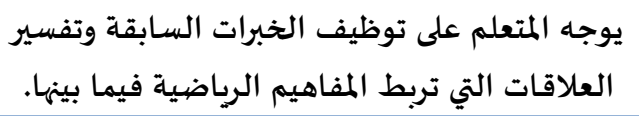 & 10 \\
\hline 3 & 0.75 & 4.19 & $\mathbf{0}$ & 1.3 & 16.3 & 45 & 37.5 & يثير مهارات التفكير الرياضي من خلال التعليق على المعطيات المتوفرة & 1 \\
\hline 4 & 0.82 & 4.18 & 0 & 5 & 11.3 & 45 & 38.8 & 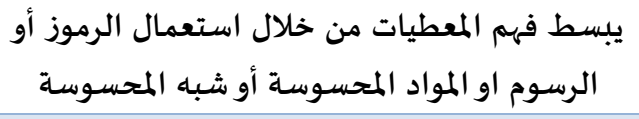 & 5 \\
\hline 5 & 0.83 & 4.06 & 1.3 & 1.3 & 20 & 45 & 32.5 & يشجع المتعلم على تقصى الحقائق والعمل على المع وفيانات المتوفرة. & 7 \\
\hline 6 & 0.87 & 4.03 & $\mathbf{0}$ & 7.5 & 13.8 & 47.5 & 31.3 & يحول المشكلة الرياضية ذات الصياغة الضببابية إلى & 3 \\
\hline 7 & 0.89 & 4.00 & 2.5 & 2.5 & 16.3 & 50 & 28.8 & يوجه المتعلم بالنظر للبيانات الرياضية على أنه & 6 \\
\hline 8 & 0.79 & 3.99 & 0 & 5 & 16.3 & 53.8 & 25 & يـحث المتعلم على المثابرة في حل المشكلة الرياضية. & 8 \\
\hline 9 & 0.98 & 3.98 & 1.3 & 7.5 & 18.8 & 37.5 & 35.0 & يشجع على إعادة صياغة المشكلة الرياضية & 4 \\
\hline
\end{tabular}




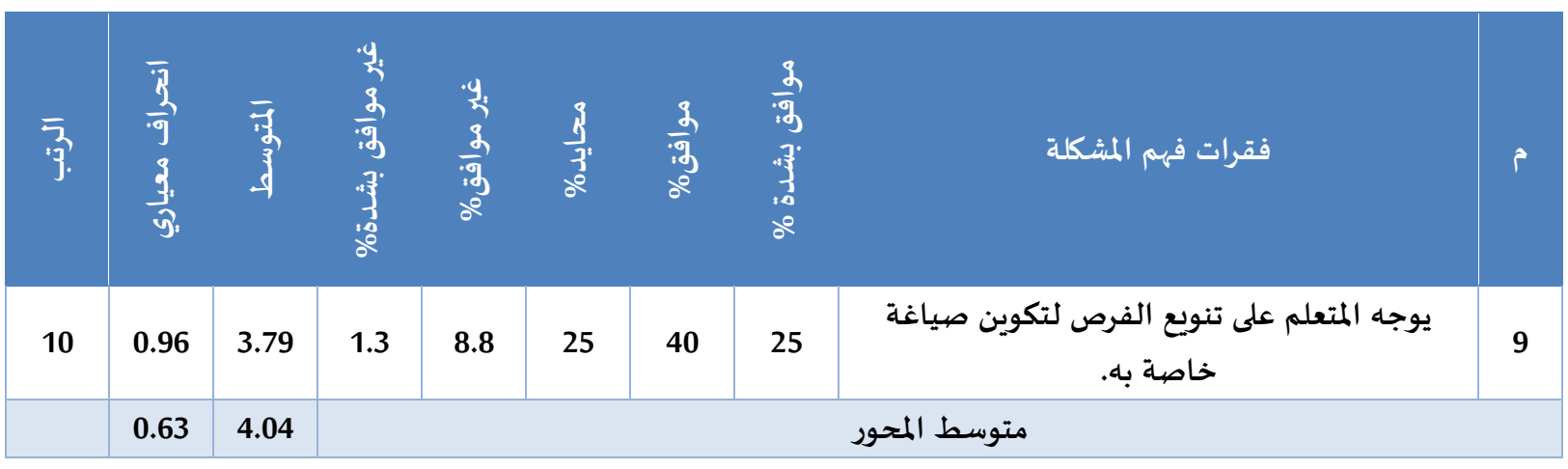

يتبين من الجدول (4) أن ممارسات معلم الرياضيات في تنمية محور فهم المشكلة لدى طلابه من وجهة نظر المختصين جاء بدرجة عالية حيث إذ بلغ المتوسط الكلي لجميع الفقرات (4.04 من 5) بانحراف معياري (0.63)،

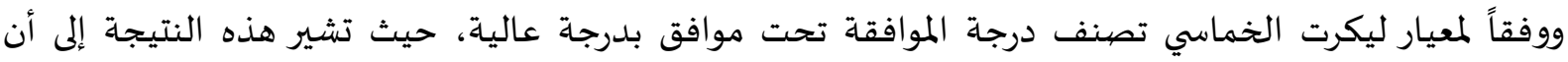
المختصين ينظرون أن الممارسات المهنية لمعلم الرياضيات دور جوهري وههم في تنمية مهارات فهم المشكلة لدى لده

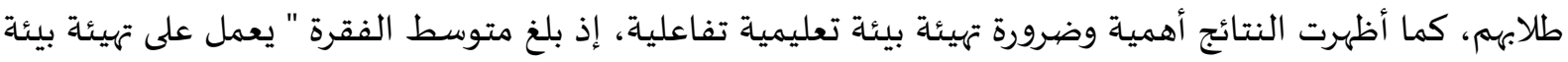
تعليمية تفاعلية" (4.23 من 5) وبانحراف معياري (0.81) ويمكن تفسير ذلك من وجهة نظر الباحث بإدراك أغلبية

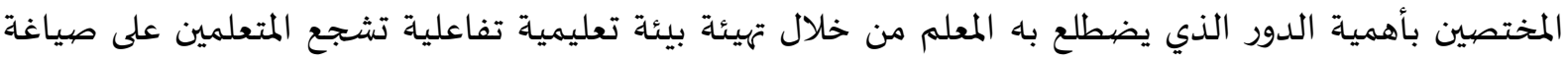

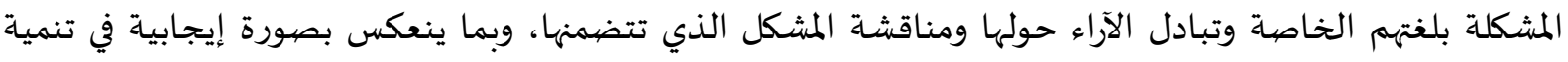

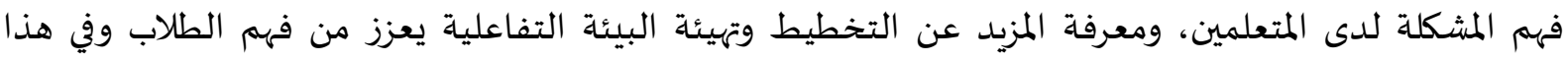
الصدد تشير العتيبي (2018) إلى أن من أبرز الاحتياجات التدريبية للمعلمين هو التخطيط وتهيئة البيئة التفاعلية،

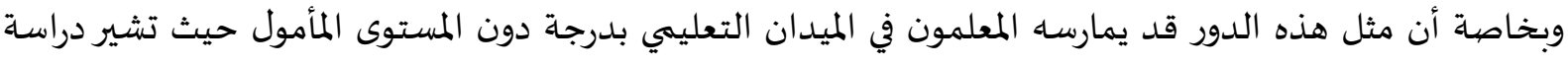

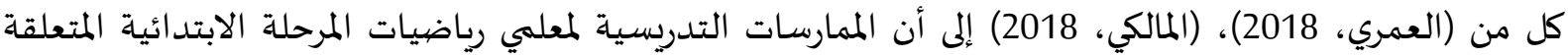
بتهيئة بيئة تعليمية تفاعلية جاءت بدرجة متوسطة. كما تظهر النتائج أهمية دور المعلم في توجيه المتعلم على توظيف الخباءت بدرات متوسهات السابقة وتفسير العلاقات التي

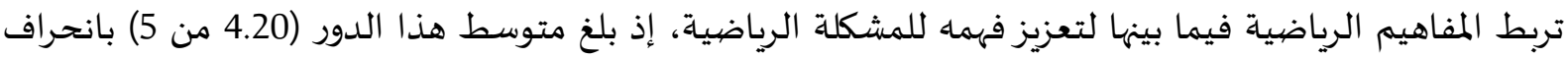

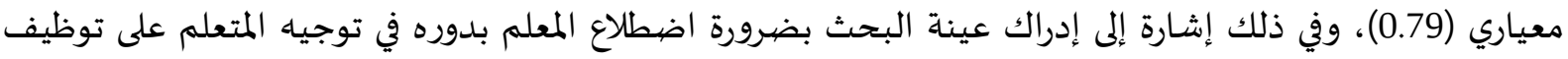

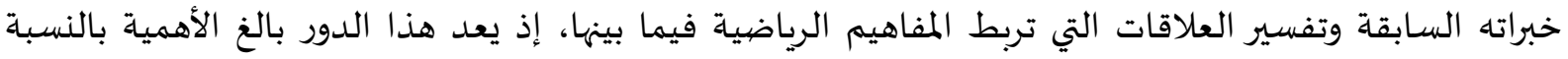

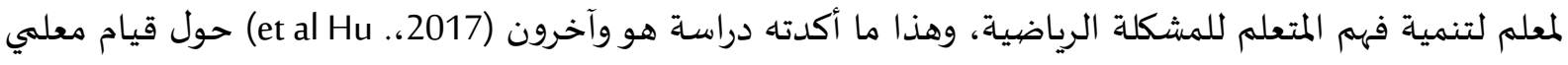
الرياضيات بطرح الأسئلة في الوقت المناسب على الطلاب وربط المعطيات المتوفرة في المشكلة الرياضية المطروحة بالخبرات السابقة والعمل على تنظيمها وتوجيه الطلاب للتعرف على أوجه الشبه أو الاختلاف بين المعطيات المبات ومعالجتها تعتبر مفتاح النجاة للعوامل التدريسية لمهارات الحل الابداعي للمشكلات التهابهات الرياضية.

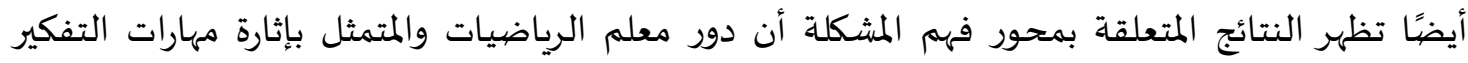
الرياضي لدى المتعلم من خلال التعليق على المعطيات المتوفرة تعد من الممارسات المهنية التي تنمي مهارة فهم المشكلة لدى طلبة المرحلة الابتدائية من وجهة نظر المختصين، إذ كان متوسط هذه الفئ الفقرة (4.19 من 5) وبانحراف معياري (0.75)، وهذا يشير إلى إدراك عين البحث بضرورة وأهمية دور معلم الرياضيات المتمثل بإثارة مهارات التفكير في فهمه مئه

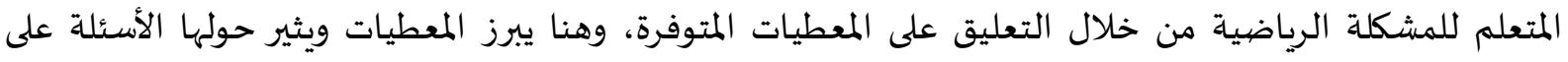

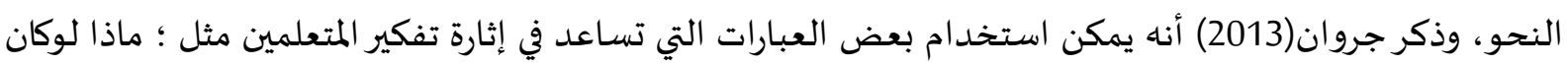

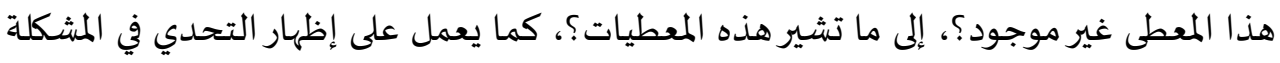


ومن الأدوار التي يرى المختصين ضرورة اضطلاع معلم الرياضيات بها أن يبسط فهم المعطيات من خلال

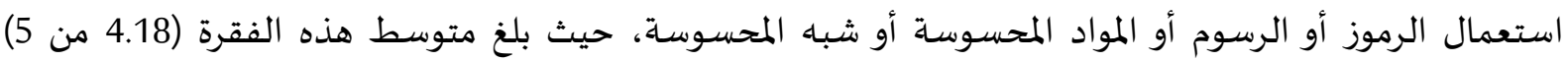

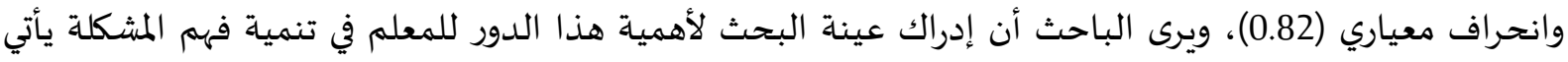

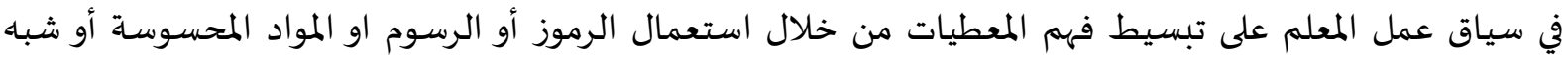

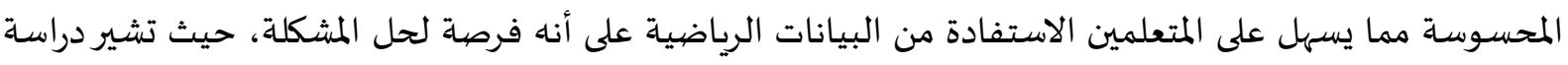

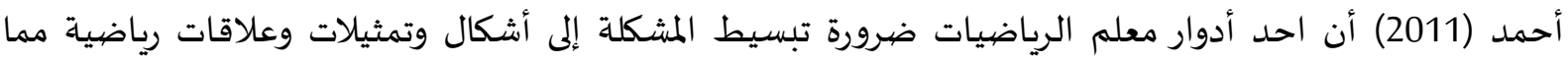

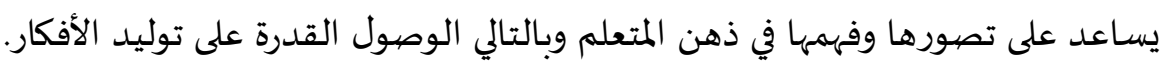

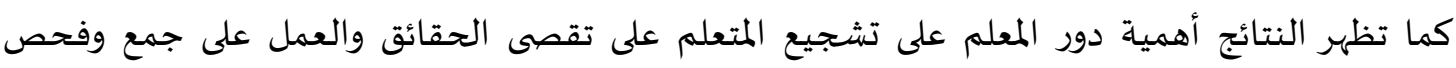

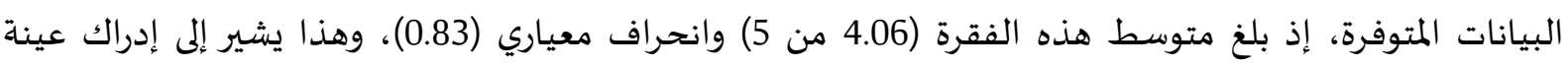

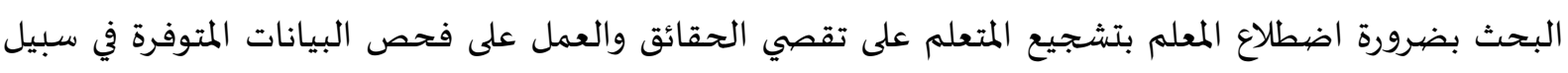

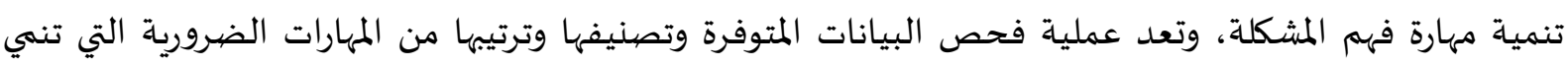

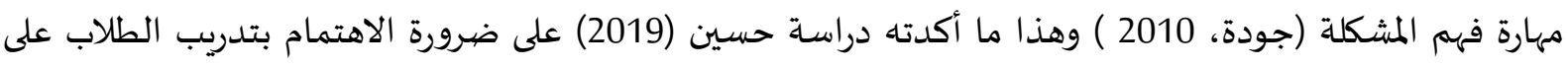

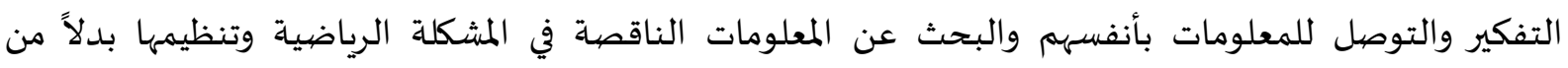
اعطائها لهم بصورة جاهزة.

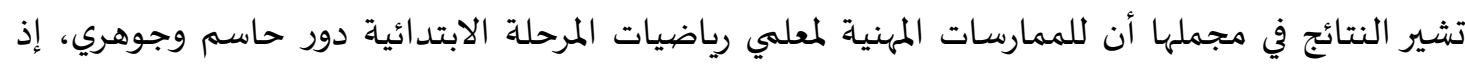

يرى المختصين وبدرجة عالية أن لهذه الممارسات دور في تنمية فهم الشكلة لدى طلبة المرحلة الابتدائية.

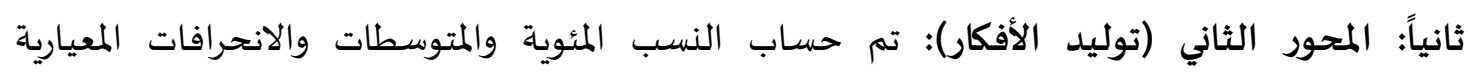

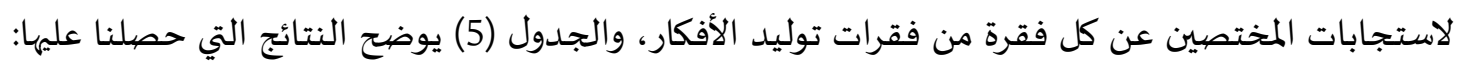
جدول (5): النسب المئوية والمتوسطات والانحرافات المعيارية لفقرات توليد الأفكار مرتبة تنازليا

\begin{tabular}{|c|c|c|c|c|c|c|c|c|c|}
\hline$\overline{3} \overline{3}$. & $\begin{array}{l}\overline{\overline{1}} \\
\bar{\sigma} \\
\vdots \\
\vdots \\
\text { के }\end{array}$ & בु & 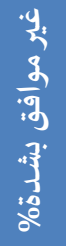 & $\begin{array}{l}\frac{y}{2} \\
\frac{j}{2} \\
2\end{array}$ & $\frac{1}{7^{*}}$ & $\frac{\xi}{2}$ & 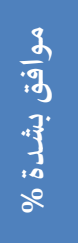 & الفقرة & $\hat{\imath}$ \\
\hline 1 & 0.81 & 4.08 & 0 & 3.8 & 17.5 & 46.3 & 32.5 & يقدم بعض الأفكار الرياضية المساعدة التي تربط المبائص الموقف المشكل والمعرفة الرياضية & 3 \\
\hline 2 & 0.93 & 4.03 & 0 & 8.8 & 15 & 41.3 & 35 & يحدد مع المتعلمين الأفكار الرياضية التي تتطلب & 2 \\
\hline 3 & 0.96 & 3.99 & 2.5 & 5 & 16.3 & 43.8 & 32.5 & 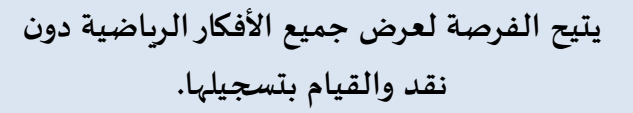 & 1 \\
\hline 4 & 0.93 & 3.98 & 1.3 & 7.5 & 13.8 & 47.5 & 30 & يشجع المتعلمين على إنتاج أكبر عدد من طرق حل المألوفة في المواقف الرياضية المختلفة & 4 \\
\hline 5 & 1.11 & 3.86 & 2.5 & 12.5 & 16.3 & 33.8 & 35 & 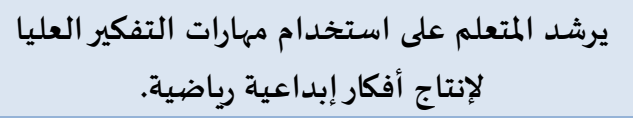 & 7 \\
\hline 6 & 1.11 & 3.88 & 3.8 & 10 & 16.3 & 35 & 35 & 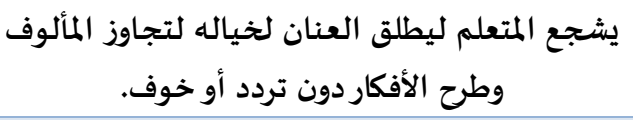 & 6 \\
\hline 7 & 1.13 & 3.80 & 2.5 & 13.8 & 18.8 & 31.3 & 33 & يحث المتعلم ليولد العديد من البدائل الرياضية & 8 \\
\hline
\end{tabular}




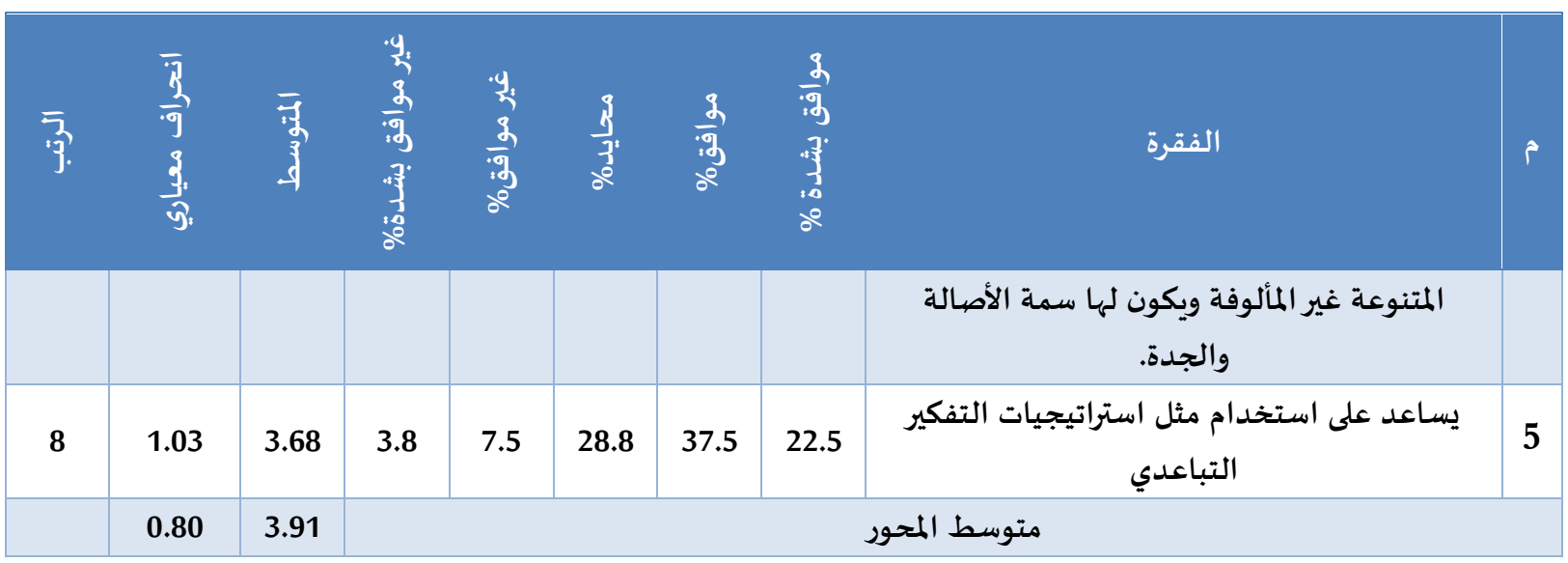

يتبين من الجدول (5) أن ممارسات معلم الرياضيات في تنمية محور توليد الأفكار لدى طلابه من وجهة نظر

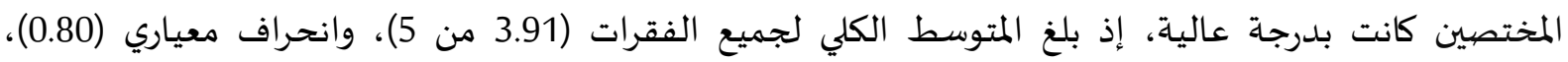

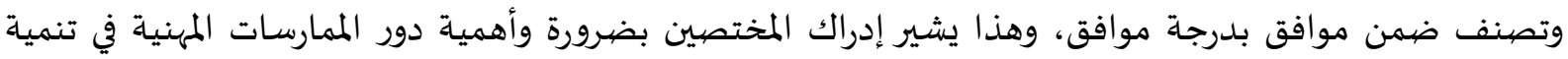

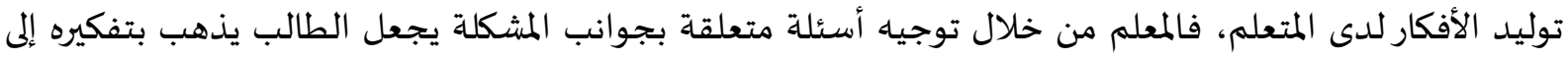

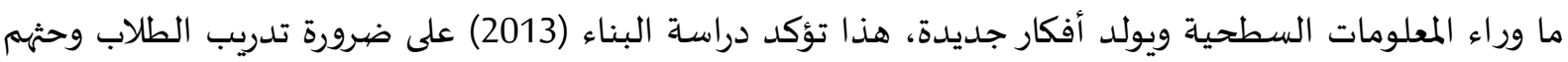
على توليد أكبر عدد من الأفكار المختلفة.

تظهر النتائج المتعلقة بهذا المحور مجموعاة من الأدوار التي يرى المختصين بضرورة اضطلاع الماع المعلم لممارستها

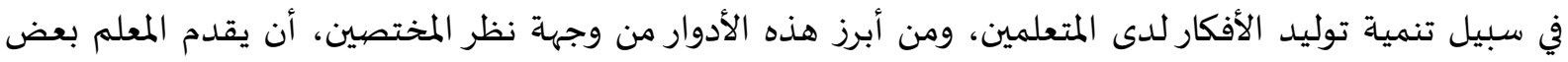

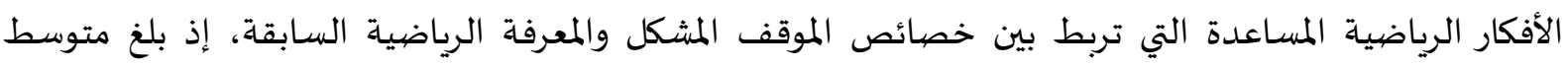

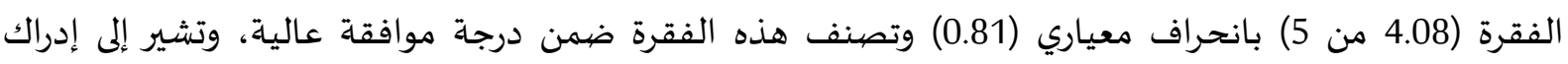

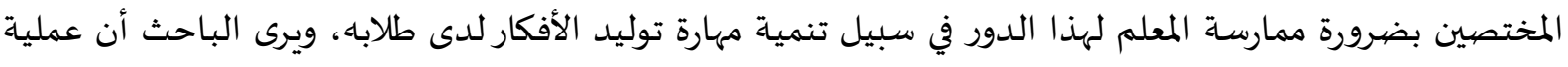
الربط بين خصائص الموقف المشكل والمعرفة الرياضية السابقة تساعد في توليد أفكار جديدة وترسم الملامح الأولية

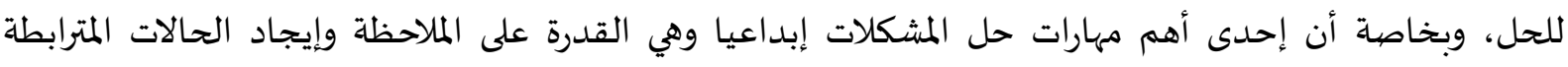

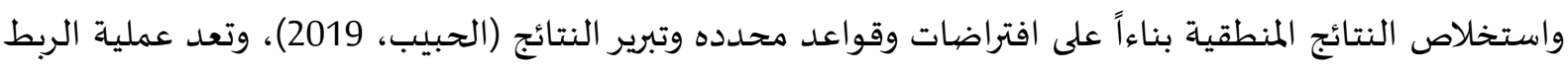
من العمليات ذات القيمة الرياضية المهمة التي ينبغي على المعلم ممارستها ومساعدة المتعلم على ممارستها، وفي هذاتيات

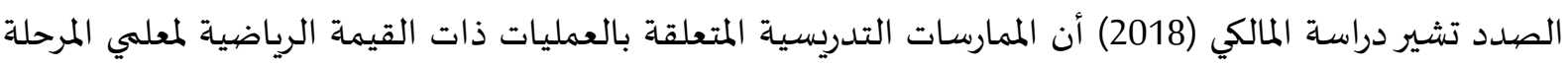

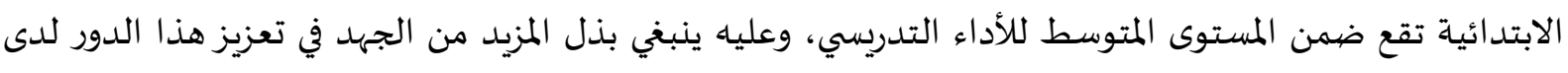
المعلم خلال حثهم للطلاب على اكتشاف معلومات جديدة، والتأمل بعمق وراء الحقائق وعدم الاكتفاء بما هو

كما تظهر النتائج أهمية دور معلم الرياضيات المتمثل بتحديد الأفكار الرياضية مع المتعلم التي تتطلب المزيد من التأمل والتفكير، إذ بلغ متوسط هذه الفقرة (4.03 من 5) وانحراف معياري (0.93)، وفي هذا إشـارة إلى إدراك

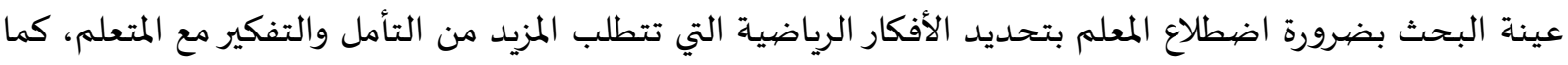

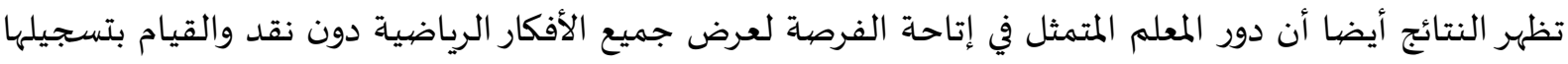

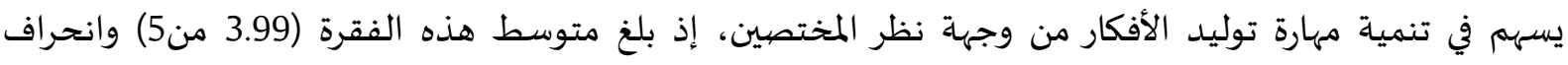

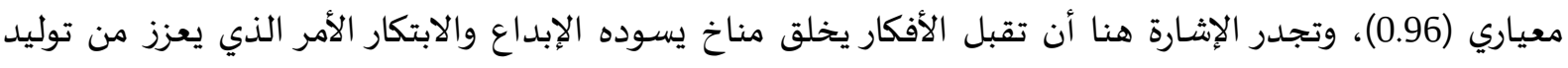

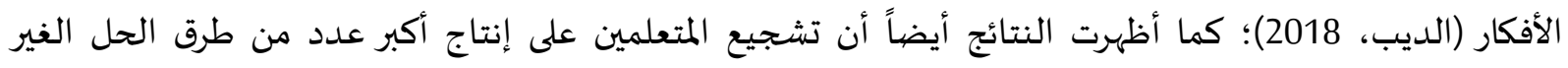

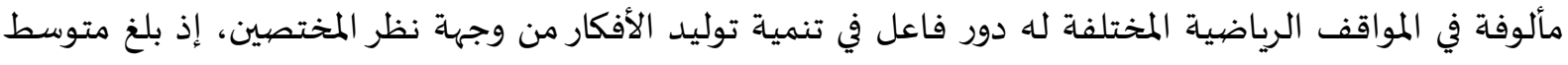


هذه الفقرة (3.98 من 5) وانحراف معياري(0.93)؛ وهذا يشير إلى إدراك المختصين بضرورة وأهمية حث المتعلمين

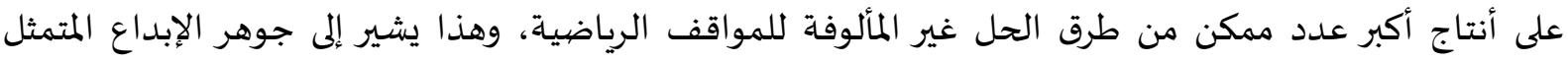

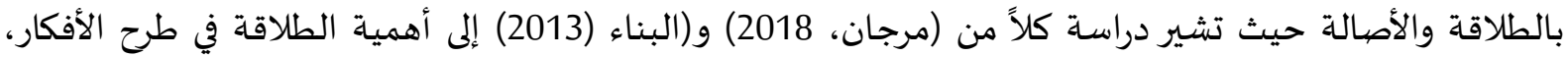
وكذلك الأصالة من خلال طرح أفكار غير مألوفة وجميع هذه العمليات تنمي مهارة توليد الأفكار لدى المتعلمين. ومن الأدوار التي يرى المختصين أنها تسهم في تنمية مهارة توليد الأفكار هو تشجيع المتعلم على إطلاق العناف العنان لخياله لتجاوز المألوف وطرح الأفكار دون تردد أو خوف، إذ بلغ متوسطات هذه الفقرة (3.88 من 5) وانحراف معياري (1.11)، حيث يؤكد (الديب، 2018) على أهمية توارد الأفكار وتعزيز دافعية الطلاب، لأنهم في الغالب يواجهون مواقف غامضاة وغير مألوفة تحتاج إلى طرح الأفكار بكل حرية ودون تردد.

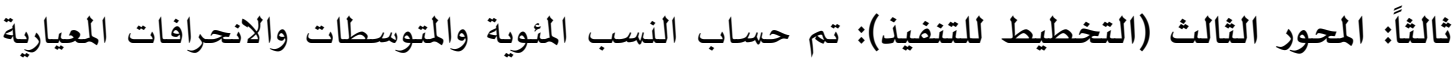

لاستجابات المختصين عن كل فقرة من فقرات التخطيط والتنفيذ والجدول (6) يوضح النتائج التي حصلنا عليها: جدول (6) النسب المئوية والمتوسطات والانحرافات المعيارية لفقرات التخطيط والتنفيذ مرتبة تنازليا

\begin{tabular}{|c|c|c|c|c|c|c|c|c|c|c|}
\hline$\overline{3}$ & $\frac{3}{\frac{1}{3}}$ & $\begin{array}{l}\frac{\bar{T}}{9} \\
\frac{9}{9} \\
\bar{y}\end{array}$ & $\bar{y}$ & 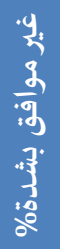 & 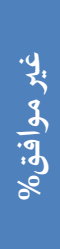 & $\frac{9}{7^{2}}$ & $\frac{\$}{2}$ & 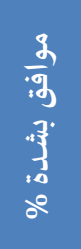 & فقرات التخطيط والتنفيذ & $\hat{\imath}$ \\
\hline 1 & عالية & 0.81 & 4.14 & 0 & 3.8 & 15 & 45 & 36.3 & والتصهورات المتعلم على معالجـة الأفكار الرياضية والبناء عليها لإنتاج أفكار & 6 \\
\hline 2 & عالية & 0.71 & 4.11 & 0 & 1.3 & 16.3 & 52.5 & 30 & يشجع على استخدام الحجج والتبريرات المنطقية & 4 \\
\hline 3 & عالية & 0.88 & 4.06 & 0 & 6.3 & 16.3 & 42.5 & 35 & وضع المعايير والمؤشرات التي يتم تقييم الحلول في & 1 \\
\hline 4 & عالية & 0.79 & 4.04 & 1.3 & 2.5 & 13.8 & 56.3 & 26.3 & يحث المتعلم على استخدام أسـاليب وعمليات & 8 \\
\hline 5 & عالية & 0.80 & 4.01 & 1.3 & 2.5 & 16.3 & 53.8 & 26.3 & يحث المتعلم على تقبل الحلول التي يتوصل إلها & 10 \\
\hline 6 & عالية & 0.91 & 3.98 & 1.3 & 5 & 20 & 42.5 & 31.3 & يعمل على تطوير قائمة بمصيادر الدعم المحتملة & 5 \\
\hline 7 & & 0.80 & 3.96 & 1.3 & 3.8 & 15 & 57.5 & 22.5 & يوجـه المتعلم على استنباط الحلول وصياغـة & 11 \\
\hline 8 & عالية & 0.95 & 3.94 & 0 & 10 & 17.5 & 41.3 & 31.3 & تجاقش جميع الأفكار الرياضية وتقييمها وعدم الجوانب الصعبة في المشكلة ودراستها & 3 \\
\hline 9 & عالية & 0.86 & 3.94 & 0 & 6.3 & 21.3 & 45.0 & 27.5 & الحججج القوية المتعلم على تقبل الإجابات والتمييز بين & 9 \\
\hline 10 & عالية & 0.79 & 3.93 & 0 & 3.8 & 23.8 & 48.8 & 23.8 & يوجه لتقييم البدائل باستخدام استراتيجيات & 2 \\
\hline 11 & عالية & 0.99 & 3.89 & 1.3 & 10 & 17.5 & 41.3 & 30 & يساعد المتعلم على إدراك العلاقات الاستنباطية & 7 \\
\hline
\end{tabular}




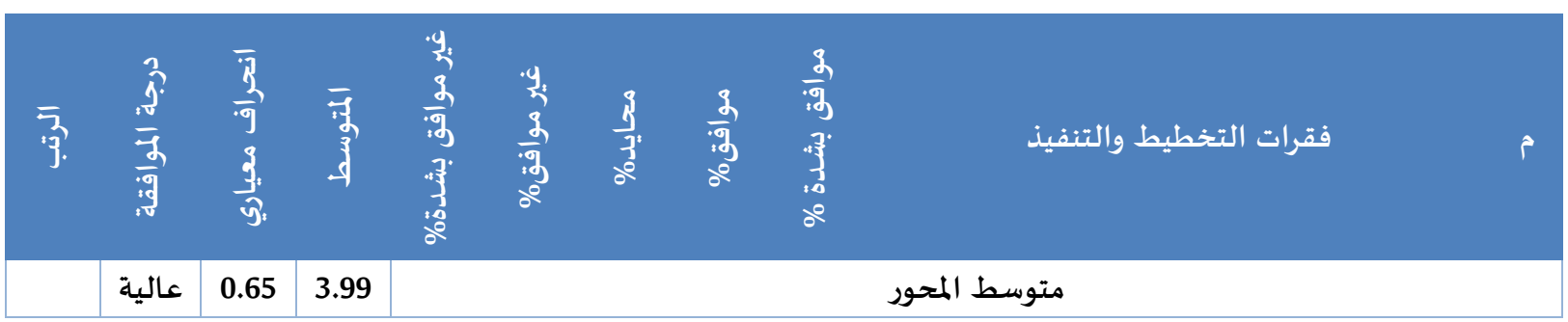

يتبين من الجدول (6) أن ممارسات معلم الرياضيات في تنمية مهارة التخطيط والتنفيذ لدى المتعلمين كانت

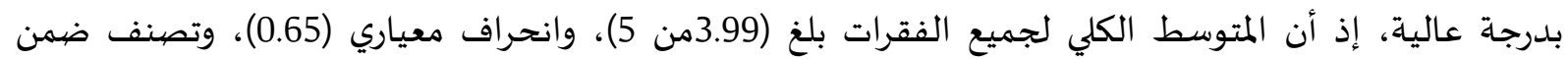

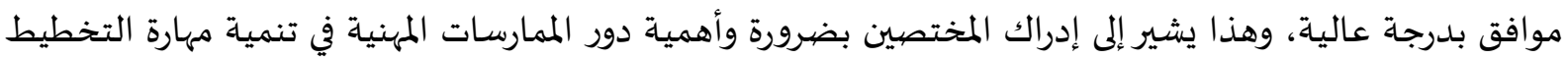

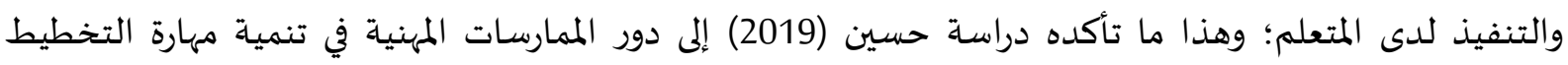
والتنفيذ.

كما تظهر النتائج المتعلقة بهذا المحور مجموعة من الأدوار التي يرى المختصين بضرورة اضطلاع المعلم

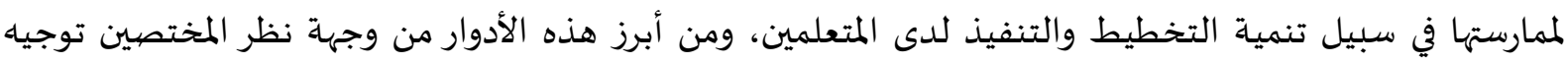

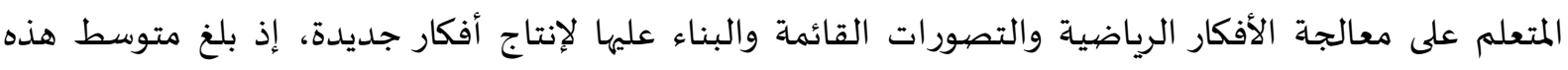

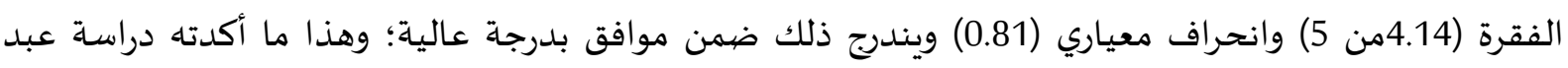

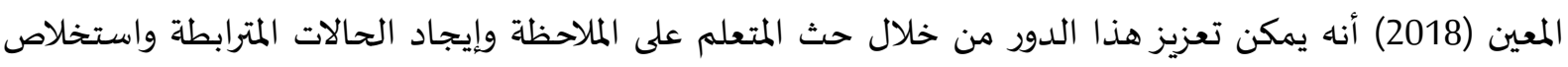

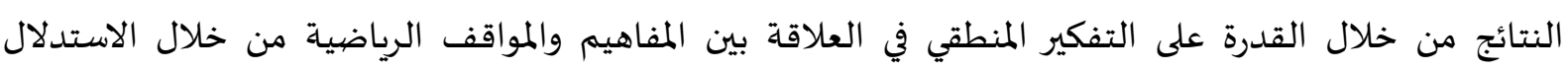
الاستقرائي والحدس الاستنتاجي. كما أظهرت النتائج أن تشجيع المتعلم على استخدام الحجج والتبرئرئرات المنطقية للإجابة يسهم في تنمية مهارة التخطيط والتنفيذ، إذ بلغ متوسط درجة موافقة المختصين على هذه الفقرة (4.11 من 5) بانحراف معياري

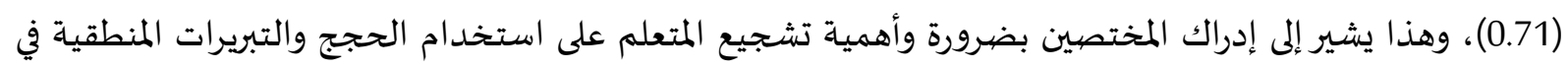

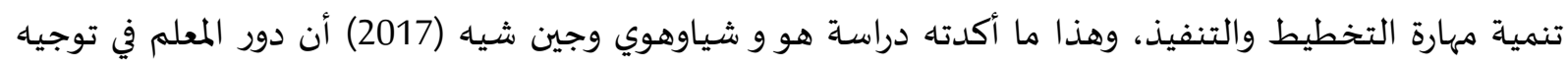

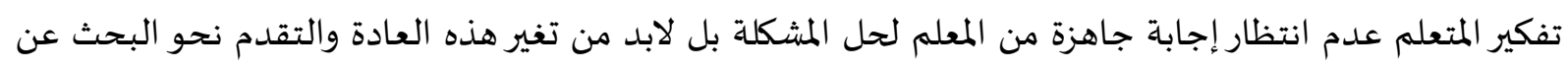

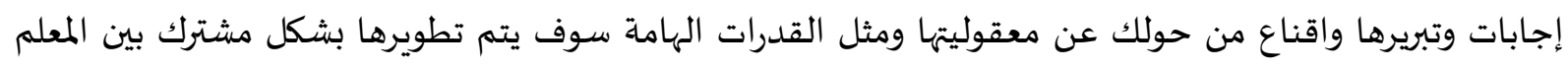

والمتعلم.

كما يرى المختصين أن وضع المعاييروالمؤشرات التي يتم تقييم الحلول في ضوئها تسهم بدرجة عالية في تنمية مهارة التخطيط والتنفيذ، إذ بلغ متوسط هذه الفقرة (4.06 من 5) وانحراف معياري (0.88)، ويمكن تعزيز مثل هذا

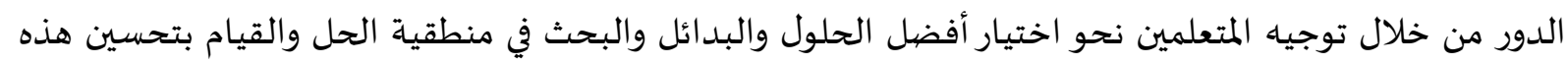

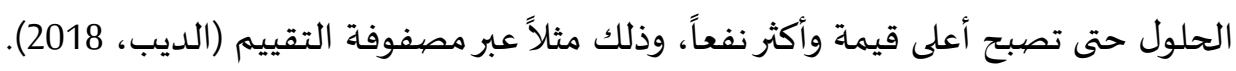

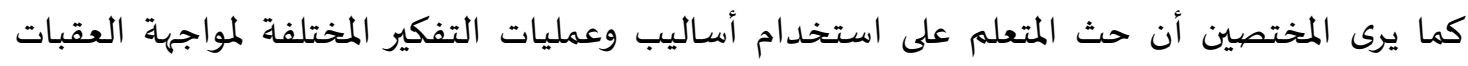

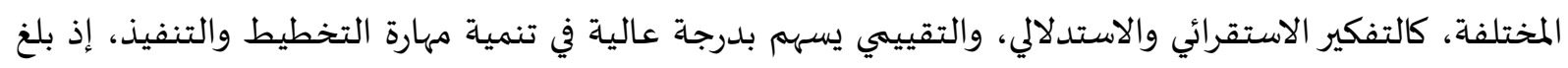

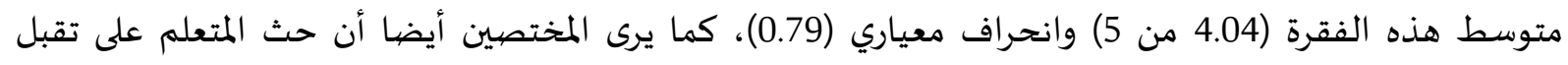

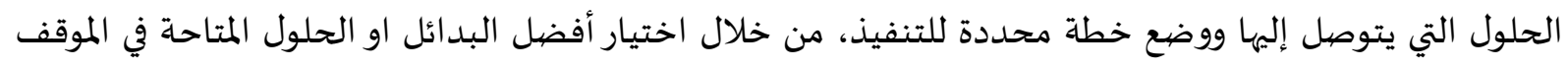

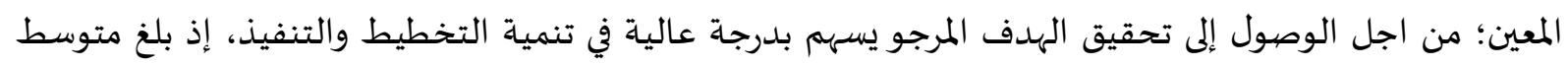

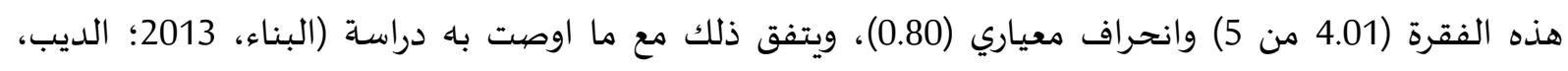




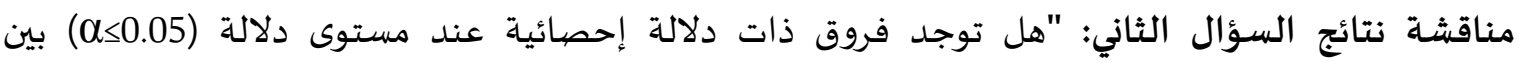

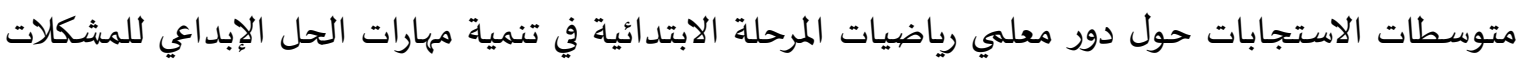

الرياضية لدى طلابهم تعزى لـ (المسهى الوظيفي، المؤهل العلمي، عدد سنوات المعات الخبرة في تعليم الرياضيات)

دراسة الفروق وفقاً للمسمى الوظيفي: للاختبار دلالة الفروق وفقاً للمسمى الوظيفي تم استخدام اختبار مان ويتني نظراً لأن المسمى الوظيفي يتألف من مستويين فقط (مشرف تربوي، معلم)، وقد استخدم هذا الاختبار اللامعلمي نظرا لعدم تحقق شرط واندار

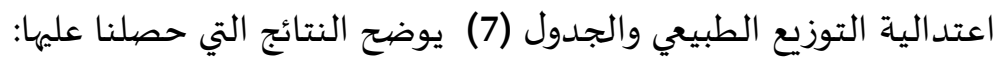
جدول (7) اختبارMann-Whitney لاختبار دلالة الفروق وفقاً لمستويات للمسمى الوظئيا: الوظيفي (مشرف تربوي،

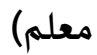

\begin{tabular}{|c|c|c|c|c|c|}
\hline Sig & قيمةة & مجموع الرتب & متوسط الرتب & $\mathbf{N}$ & المسيمى الوظيفي \\
\hline \multicolumn{6}{|c|}{ المحور الأول: فهم المشكلة } \\
\hline \multirow{2}{*}{0.193} & \multirow{2}{*}{-1.302} & 1124 & 36.26 & 31 & مشرف تربوي \\
\hline & & 2116 & 43.26 & 49 & 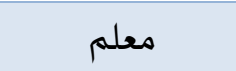 \\
\hline \multicolumn{6}{|c|}{ المحور الثاني: توليد الأفكار } \\
\hline \multirow{2}{*}{0.125} & \multirow{2}{*}{-1.536} & 100.5 & 35.5 & 31 & مشرف تربوي \\
\hline & & 2139.5 & 43.66 & 49 & 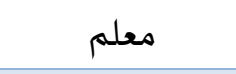 \\
\hline \multicolumn{6}{|c|}{ المحور الثالث: التخطيط والتنفيذ } \\
\hline \multirow{2}{*}{0.130} & \multirow{2}{*}{-1.515} & 1102.5 & 35.56 & 31 & مشرف تربوي \\
\hline & & 2137.5 & 43.62 & 49 & 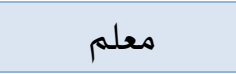 \\
\hline \multicolumn{6}{|c|}{ 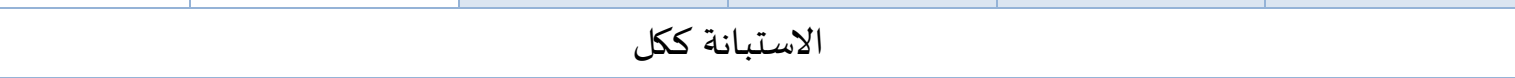 } \\
\hline \multirow{2}{*}{0.139} & \multirow{2}{*}{-1.478} & 1106 & 35.68 & 31 & مشرف تربوي \\
\hline & & 2134 & 43.55 & 49 & معلم \\
\hline
\end{tabular}

دراسة الفروق وفقاً للمؤهل العلمي: لاختبار دلالة الفروق وفقاً للمؤهل العلمي تم استخدام اختبار مان ويتني نظراً لأن المؤهل العلمي يتألف من

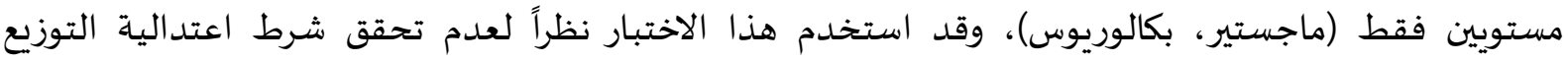

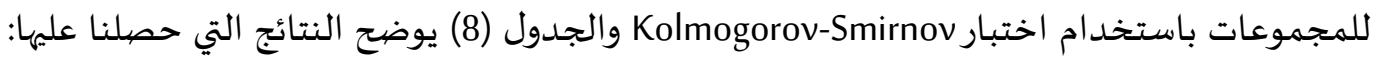
جدول (8) اختبار Mann-Whitney لاختبار دلالة الفروق وفقاً للمؤهل العلمي

\begin{tabular}{|c|c|c|c|c|c|}
\hline Sig & قيمةZ & مجموع الرتب & متوسط الرتب & $\mathbf{N}$ & المؤهل العلمي \\
\hline \multicolumn{6}{|c|}{ المحور الأول: فهم المشكلة } \\
\hline \multirow{2}{*}{0.031} & \multirow{2}{*}{-2.159} & 2734.5 & 43.4 & 63 & بكالوريوس \\
\hline & & 505.5 & 29.74 & 17 & ماجستير \\
\hline \multicolumn{6}{|c|}{ المحور الثاني: توليد الأفكار } \\
\hline 0.032 & -2.141 & 2733 & 43.38 & 63 & بكالوريوس \\
\hline
\end{tabular}


المجلة العربية للطوم ونشر الأبحاث ـ مجلة العلوم التربوية والنفسية ـ المجلد الخامس ـ العدد الثالث والثلاثون ـ سبتمبر 2021م

\begin{tabular}{|c|c|c|c|c|c|}
\hline Sig & 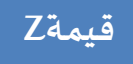 & مجموع الرتب & متوسط الرتب & $\mathbf{N}$ & المؤهل العلمي \\
\hline & & 507 & 29.82 & 17 & ماجستير \\
\hline \multicolumn{6}{|c|}{ المحور الثالث: التخطيط والتنفيذ } \\
\hline \multirow{2}{*}{0.06} & \multirow{2}{*}{-1.887} & 2711.5 & 43.04 & 63 & 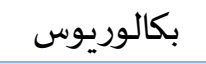 \\
\hline & & 528.5 & 31.09 & 17 & ماجستير \\
\hline \multicolumn{6}{|c|}{ الاستبانة ككل } \\
\hline \multirow{2}{*}{0.022} & \multirow{2}{*}{-2.291} & 2746 & 34.59 & 63 & بكالوريوس \\
\hline & & 494 & 29.06 & 17 & ماجستير \\
\hline
\end{tabular}

دراسة الفروق وفقاً لسنوات الخبرة في تعليم الرياضيات:

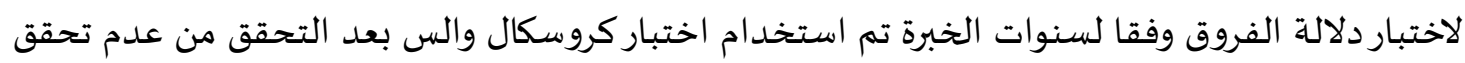

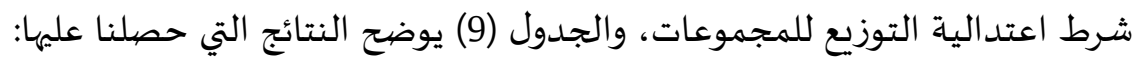

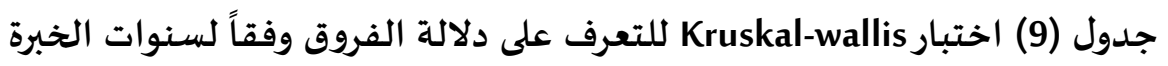

\begin{tabular}{|c|c|c|c|c|c|}
\hline Sig & درجة الحرية & قيمة مريع كاي & متوسط الرتب & $\mathbf{N}$ & 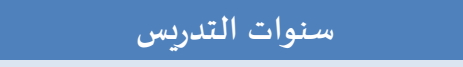 \\
\hline \multicolumn{6}{|c|}{ المحتور الأول: فهم المشكلة } \\
\hline \multirow{4}{*}{0.01} & \multirow{4}{*}{3} & \multirow{4}{*}{11.27} & 35.07 & 42 & 15 سنة فأكثر \\
\hline & & & 49.36 & 18 & من 10 سنوات إلى أقل من 15 سنة \\
\hline & & & 43.69 & 13 & من 5 سنوات إلى أقل من 10 سنوات \\
\hline & & & 61.07 & 7 & أقل من 5 سنوات \\
\hline \multicolumn{6}{|c|}{ المحور الثاني: توليد الأفكار } \\
\hline \multirow{4}{*}{0.02} & \multirow{4}{*}{3} & \multirow{4}{*}{15.21} & 34.30 & 42 & 15 سنة فأكثر \\
\hline & & & 51.33 & 18 & من 10 سنوات إلى أقل من 15 سنة \\
\hline & & & 33.12 & 13 & من 5 سنوات إلى أقل من 10 سنوات \\
\hline & & & 63.57 & 7 & أقل من 5 سنوات \\
\hline \multicolumn{6}{|c|}{ المحور الثالث: التخطيط والتنفيذ } \\
\hline \multirow{4}{*}{0.06} & \multirow{4}{*}{3} & \multirow{4}{*}{7.392} & 37.39 & 42 & 15 سنة فأكثر \\
\hline & & & 44.33 & 18 & من 10 سنوات إلى أقل من 15 سنة \\
\hline & & & 34.42 & 13 & من 5 سنوات إلى أقل من 10 سنوات \\
\hline & & & 60.57 & 7 & أقل من 5 سنوات \\
\hline \multicolumn{6}{|c|}{ الاستبانة ككل } \\
\hline \multirow{4}{*}{0.007} & \multirow{4}{*}{3} & \multirow{4}{*}{12.158} & 35.23 & 42 & ا 15 سنة فاكثر \\
\hline & & & 48.92 & 18 & من 10 سنوات إلى أقل من 15 سنة \\
\hline & & & 33.81 & 13 & من 5 سنوات إلى أقل من 10 سنوات \\
\hline & & & 62.93 & 7 & أقل من 5 سنوات \\
\hline
\end{tabular}

أظهرت النتائج المتعلقة بالفروق وفقاً للمسمى الوظيفي أنه لا يوجد فرق دال إحصائياً بين متوسطي

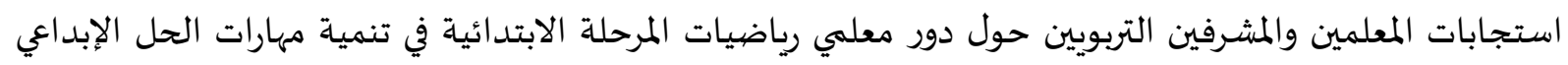

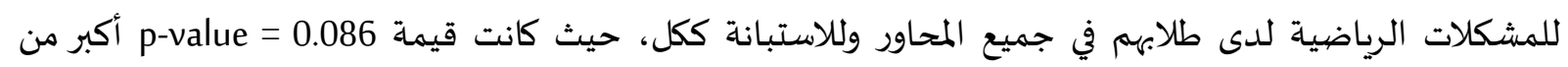


(0.05)؛ وهذا يشير إلى اتفاق عينة البحث وفقاً للمسهى الوظيفي وإجماعهم حول دور معلمي رياضيات المرحلة

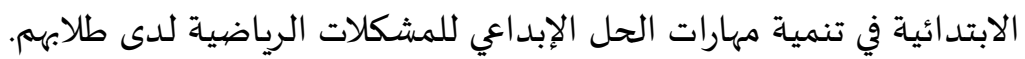

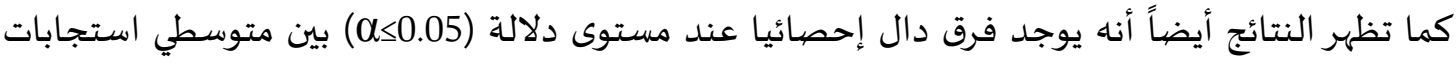

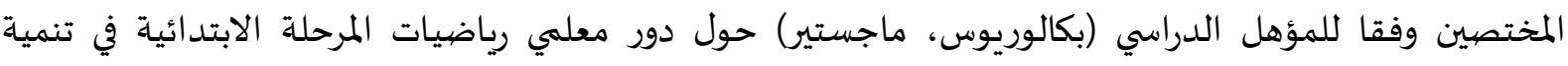

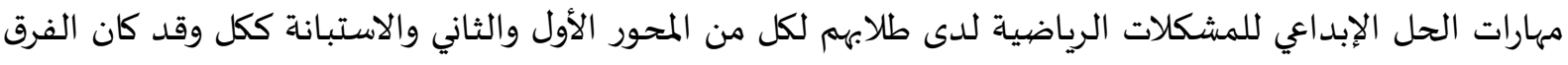

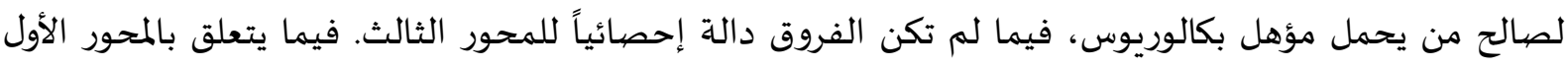

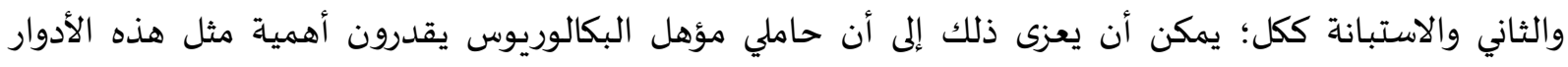

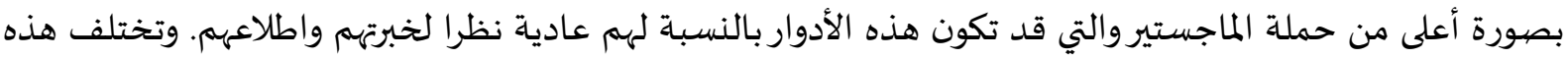

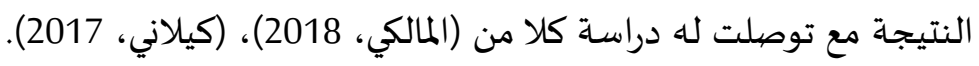

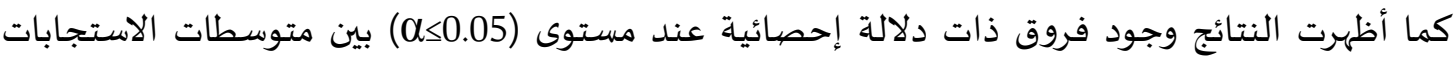

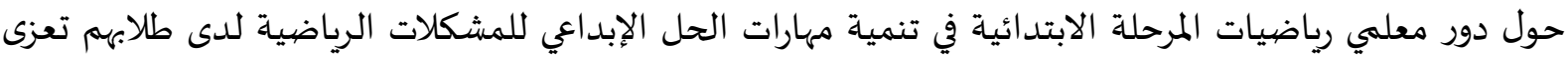

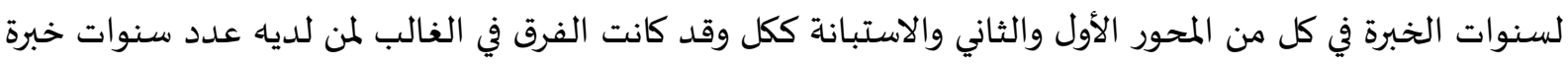

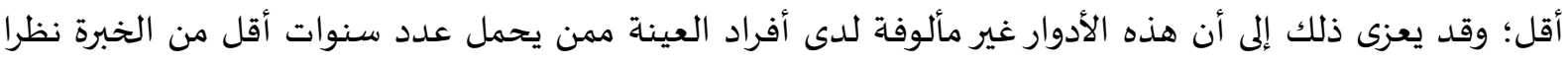

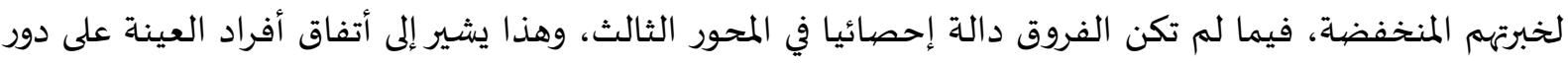

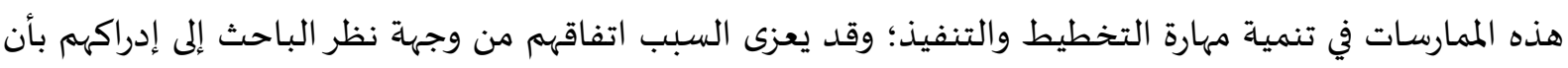

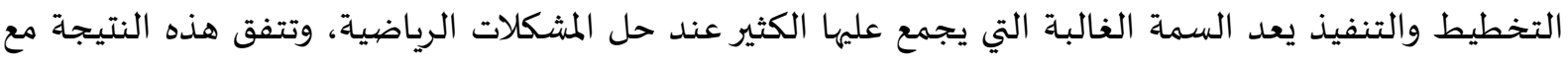

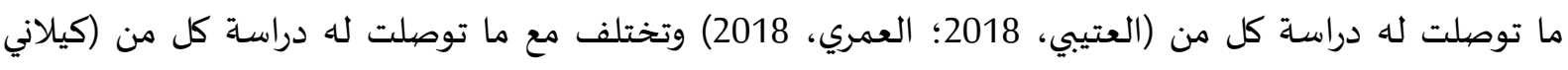
2017؛ المالكي، 2018).

توصيات الدراسـة ومقترحاتها.

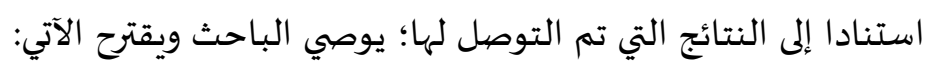

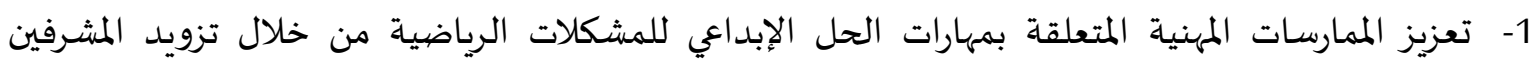
التربويين بالتصور المقترح الذي خرج باته هذا البحث.

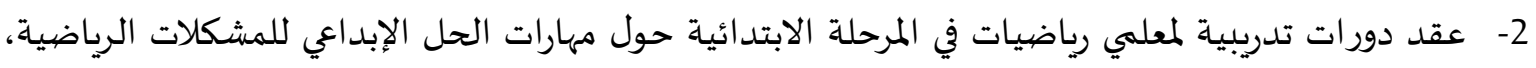
يتضمن ذلك دليل إرشادي مفصل حول مهارات الحل الإبداعي.

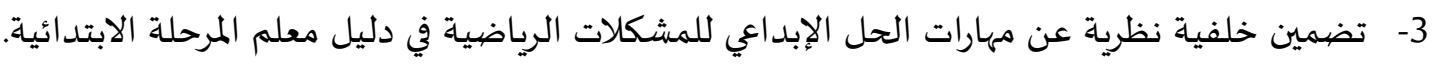

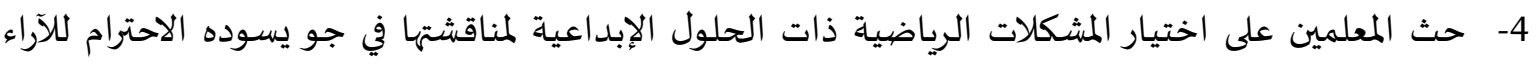

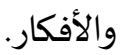

\footnotetext{
5- كما يقترح الباحث إجراء دراسات في الموضوعات الآتية:

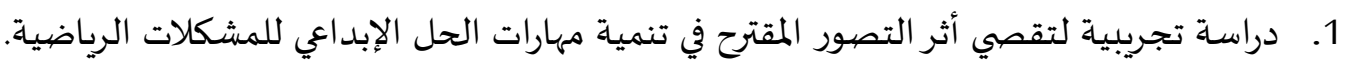

2. دراسة كيفية عن نوعية المشكلات الرياضية التي تقدم للمتعلمين في المرحلة الابتدائية.

3. تحليل كتب المرحلة الابتدائية للتعرف على مدى تضمينها للمشكلات الرياضية التي تتطلب الحلول الإبداعية.
} 
- أحمد محمد قبلان (2018م). أسباب التراجع المستمر في الأداء الأكاديمي لطلبة الصف الثامن الأساسي في الأردن

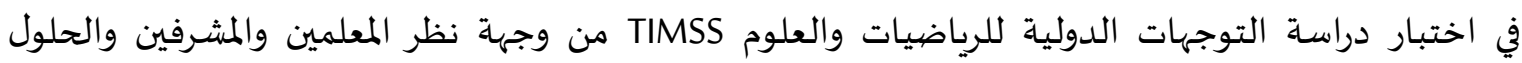
المقترحة لمعالجتها. مجلة مؤتة للبحوث والدراسات. سلسلة العلوم الإنسانية. 33(4). 123-154.

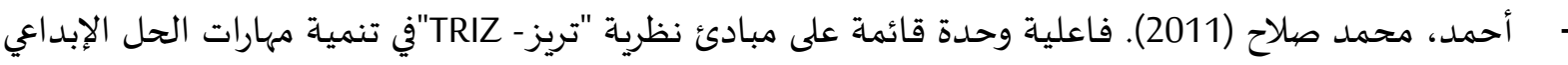
للمشكلات الرياضية لدى طلاب المرحلة الإعدادية. مجلة تربويات الرياضيات. الجمعية المصرية لتربويات الرياضيات.14(1). - الأعسر، صيفاء يوسف. (2007م). الإبداعي في حل المشكلات. (ط2). الرياض: دار الأزهر للنشروالتوزيع.

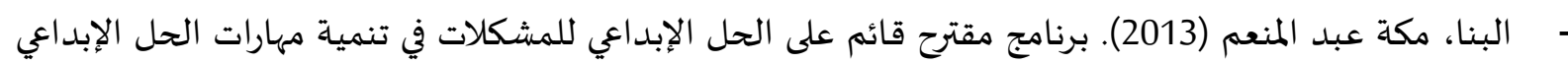

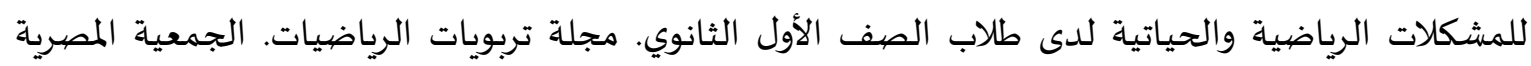
لتربويات الرياضيات. 16(2). 180- 247. جودة، جيهان محمود، (2010). ابداعات المعلم العربي الحل الإبداعي للمشكلات (مفاهيم وتدرببات). عمّان: دار الفكر حسن، إبراهيم محمد (2017). فاعلية برنامج تدريبي قائم على المعايير العالمية لمعلهي الموهوبين في تنمية الكفاءة الذاتية للمعلمين والحل الإبداعي للمشكلات الرياضية لدى تلاميذهم الموهوبين. مجلة كلية التربية. جامعة بنهاكلية التربية.28(110). 103 - 154 حسين، إبراهيم التونسي السيد (2019). فاعلية برنامج قائم على عادات العقل في تعلم الرياضيات لتنمية

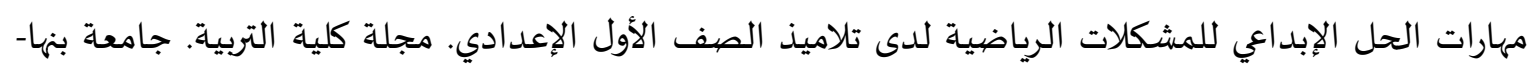
كلية التربية 30 (118). 201- 230.

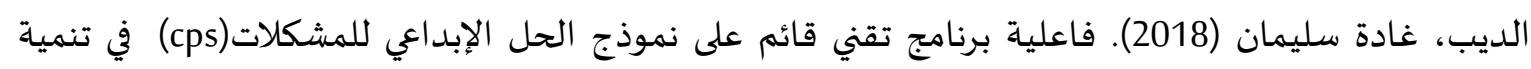

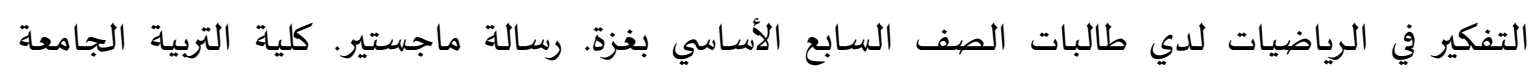
الإسلامية (غزة) السبيل، فاطمة علي (2017). واقع أداء معلمات الرياضيات في المرحلة المتوسطة لمسائل مهارات التفكير العليا

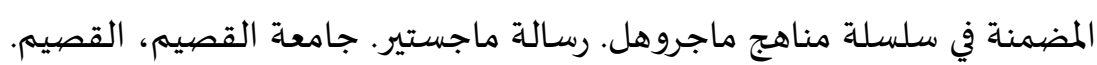

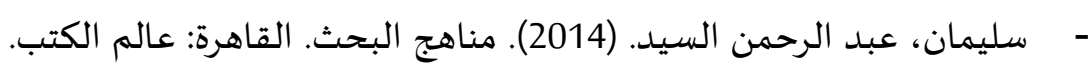
الشلهوب، سمر عبد العزيز (2019). برنامج إثرائي مقترح قائم على دمج مبادئ نظرية تريز

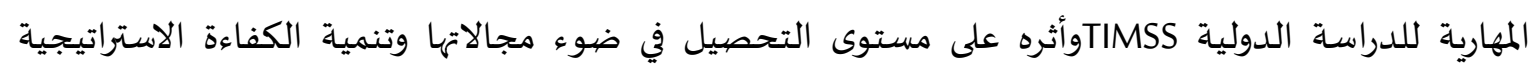

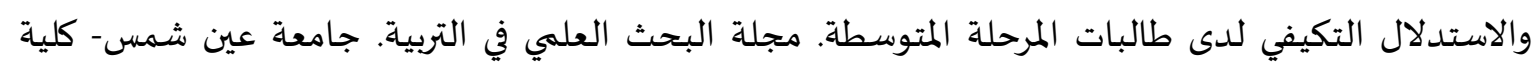
البنات للآداب والعلوم والتربية.20(7) 391- 435.

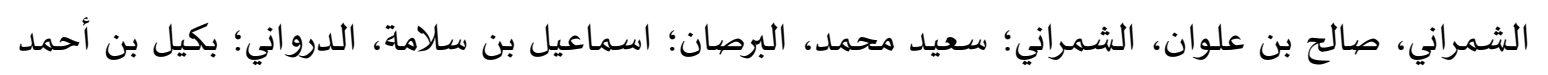

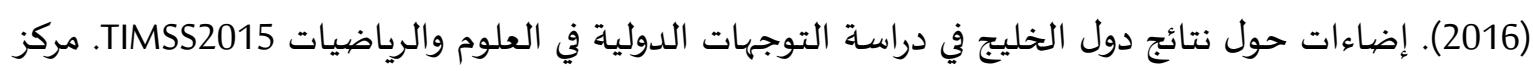
التميز البحثي في تطوير تدريس العلوم والرياضيات، جامعات نول دول الملك سعود. الرياض. 
- الشهري، ظافر بن فراج هزاع (2018). درجة ممارسة معلمات الرياضيات بالتعليم العام لمهارات التفكير الابداعي.

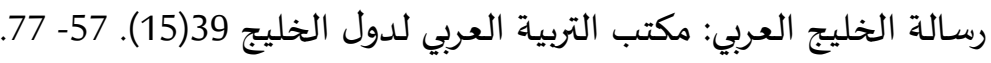

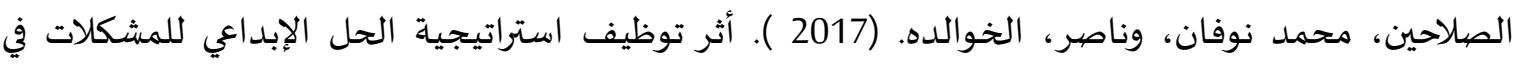

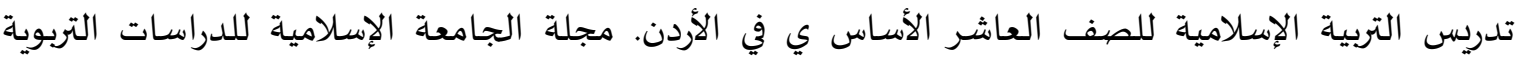
والنفسية، 26(5)، ص. 344-324.

العتيبي، بيان بن بين (2018). الاحتياجات التدريبية اللازمة لمعلمي الرياضيات في المرحلة الابتدائية التابعة لمركز

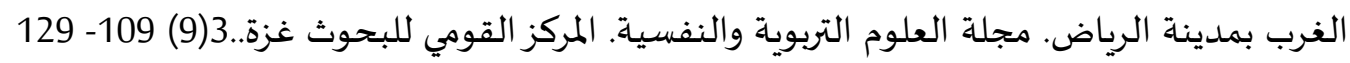
عقيلان، إبراهيم محمد (2015). مناهج الرياضيات وأساليب تدريسها. ط 2. عمان: دار المسيرة للنشر والتوزيع والطباعة.

عكاشة؛ حمود فتحى، سرور؛ سعيد عبد الغنى، المدبولي؛ رشا عبد السلام (2011). تنمية مهارات الحل الإبداعي المشكلات لدى معلمي العلوم وأثره على أداء تلاميذهم. المجلة العربية لتطوير التفوق. (2). 1V- 10. العمري، نورة بنت علي (2018). مستوى الممارسات التدريسية في ضوء النظرية البنائية لدى معلمي ومعلمات الرياضيات في المرحلتين الابتدائية والمتوسط بمدينة نجران. مجلة تربويات الريات الرياضيات. الجمعية المصرية لتربويات الرياضيات 21(5)، 219- 253.

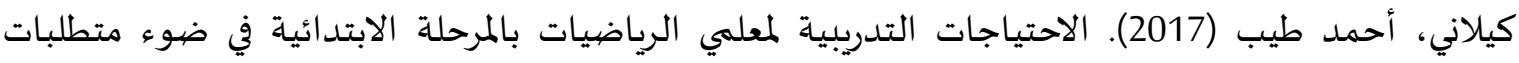
تحقيق أهداف مناهج الرياضيات المطورة من سلسلة ماقروهل التعليمية بالمرحلة الابتدائية. مجلة كلية التربية. جامعة أسيوط- كلية التربية.33(4). 59- 81. لالفي، سعيد (2015). تنمية الابداع. القاهرة: عالم الكتب. المالكي، عماد بن عبد الله (2018). مستوى ممارسات التدريس لدى الديد معلمي الرياضيات بالماتلمرحلة الابتدائية في ضوء معايير تعليم وتعلم الرياضيات. مجلة تربويات الرياضيات. الجمعية المصرية لتربويات الرياضيات.21(2). $.160-135$

مرجان، سمر محمد (2018). فاعلية برنامج قائم على تسريع التفكير في الرياضيات "CAME" لتنمية الحل

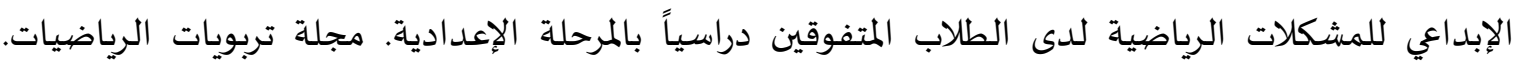
الجمعية المصرية لتربويات الرياضيات.21(11) 308- 325. النعيمي، شيخة بنت ظلام (2018). أثر برنامج تدريبي مقترح قائم على نموذج الحل الإبداعي للمشكلات (CPS) في

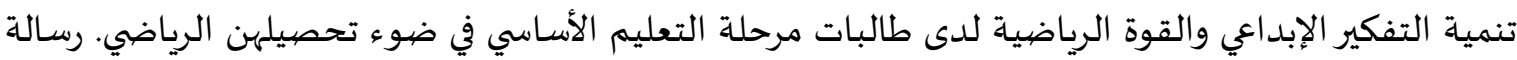
دكتوراه. جامعة السلطان قابوس، مسقط. هيئة تقويم التعليم والتدريب. (2019م). وثيقة معايير مجال تعلم الرياضيات. تم الاسترجاع بتاريخ https: //www.etec.gov.sa/ar/StandardsEducational/CriteriaByClassesAnd :2019/12/07 من الرابط:

DimensionsIncluded/Pages/p8.aspx هيئة تقويم التعليم والتدريب. (2020). المملكة تحقق ارتفاعًا في نتائج تحصيل الطلبة في اختبار "TIMSS" لعام

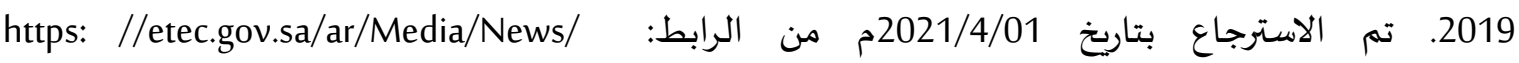
Pages/TIMSS.aspx - - هيئة تقويم التعليم والتدريب. (2020). وثيقة المعايير معلمي الرياضيات-1. تم الاسترجاع بتاريخ 2021/4/03م

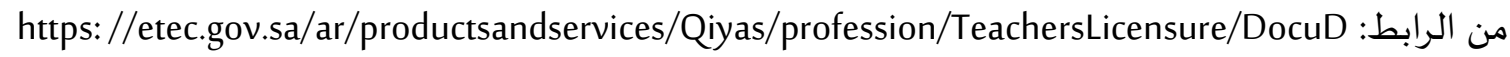


- A Muin, M, A, Hanifah, S H, Diwidian, F. (2018). The effect of creative problem solving on students' mathematical adaptive reasoning, Journal of Physics: Conference Series, (948), 1-6.

- Hu, R, Xiaohui, S, Shieh, C. (2017). A Study on the Application of Creative Problem Solving Teaching to Statistics Teaching. Eurasia Journal of Mathematics, Science and Technology Education, 13(7), 31393149.

- Sophonhiranrak, S, Suwannatthachote, P, Ngudgratoke, S. (2015). Factors Affecting Creative Problem Solving in the Blended Learning Environment: A Review of the Literature, Procedia- Social and Behavioral Sciences, (174), 2130-2136 